\title{
Inverse modelling of Köhler theory - Part 1: A response surface analysis of CCN spectra with respect to surface-active organic species
}

Samuel Lowe et al.

Correspondence to: Daniel G. Partridge (dan.partridge@aces.su.se)

The copyright of individual parts of the supplement might differ from the CC-BY 3.0 licence. 


\section{Response surfaces}

Here all response surfaces are supplied for the interested reader. Surfaces for each of the partitioning schemes (Nos. 1-4) discussed in Sect. 2 of the main text are presented in the same sequential order. Sections 1.1-1.3 correspond to the marine average, rural continental and polluted continental environments, respectively. 


\subsection{Marine average}

1.1.1 Case 1: $a_{w}^{n p} \sigma^{f}$
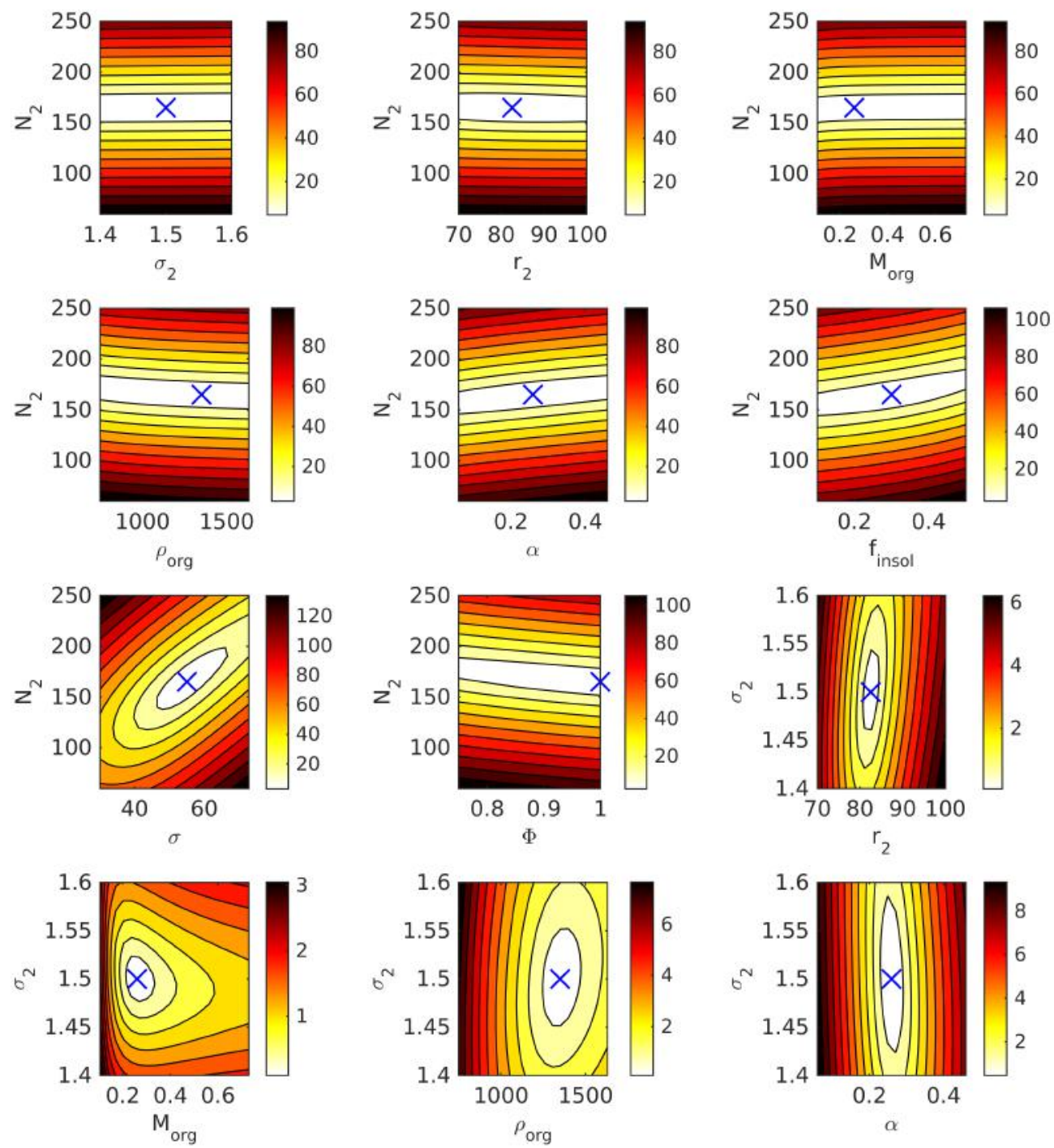

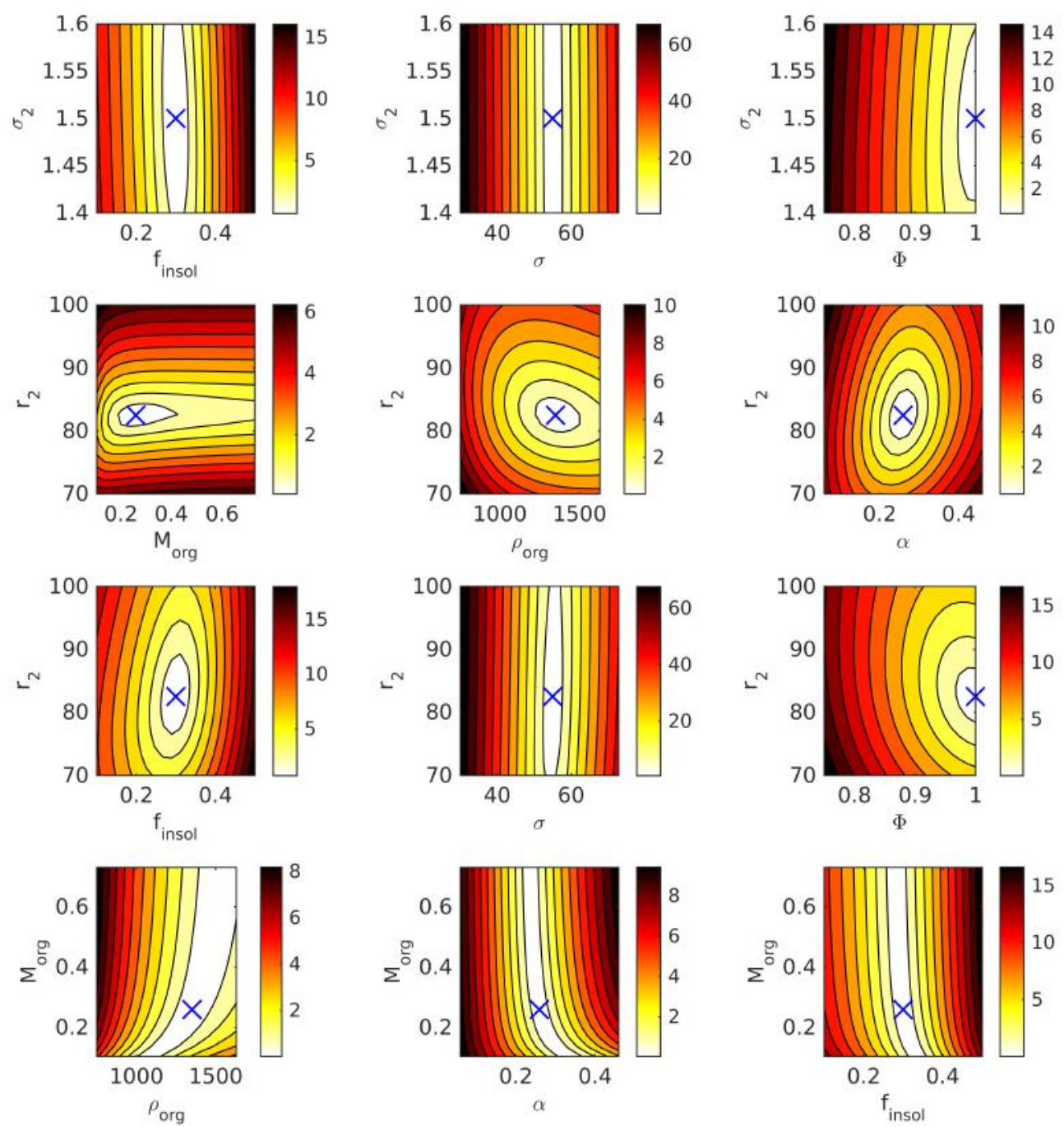

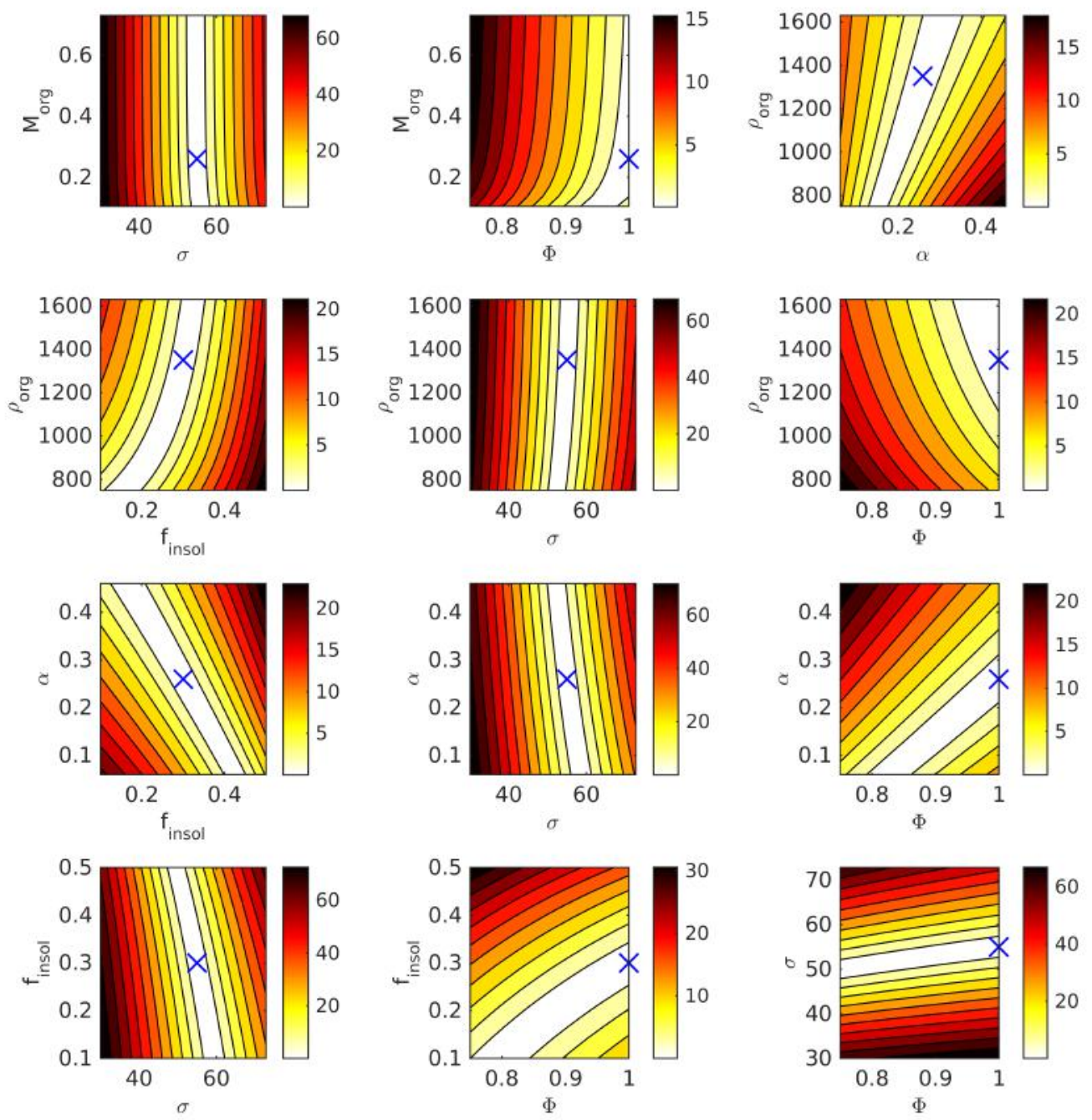


\subsubsection{Case 2: $a_{w}^{p} \sigma^{f}$}
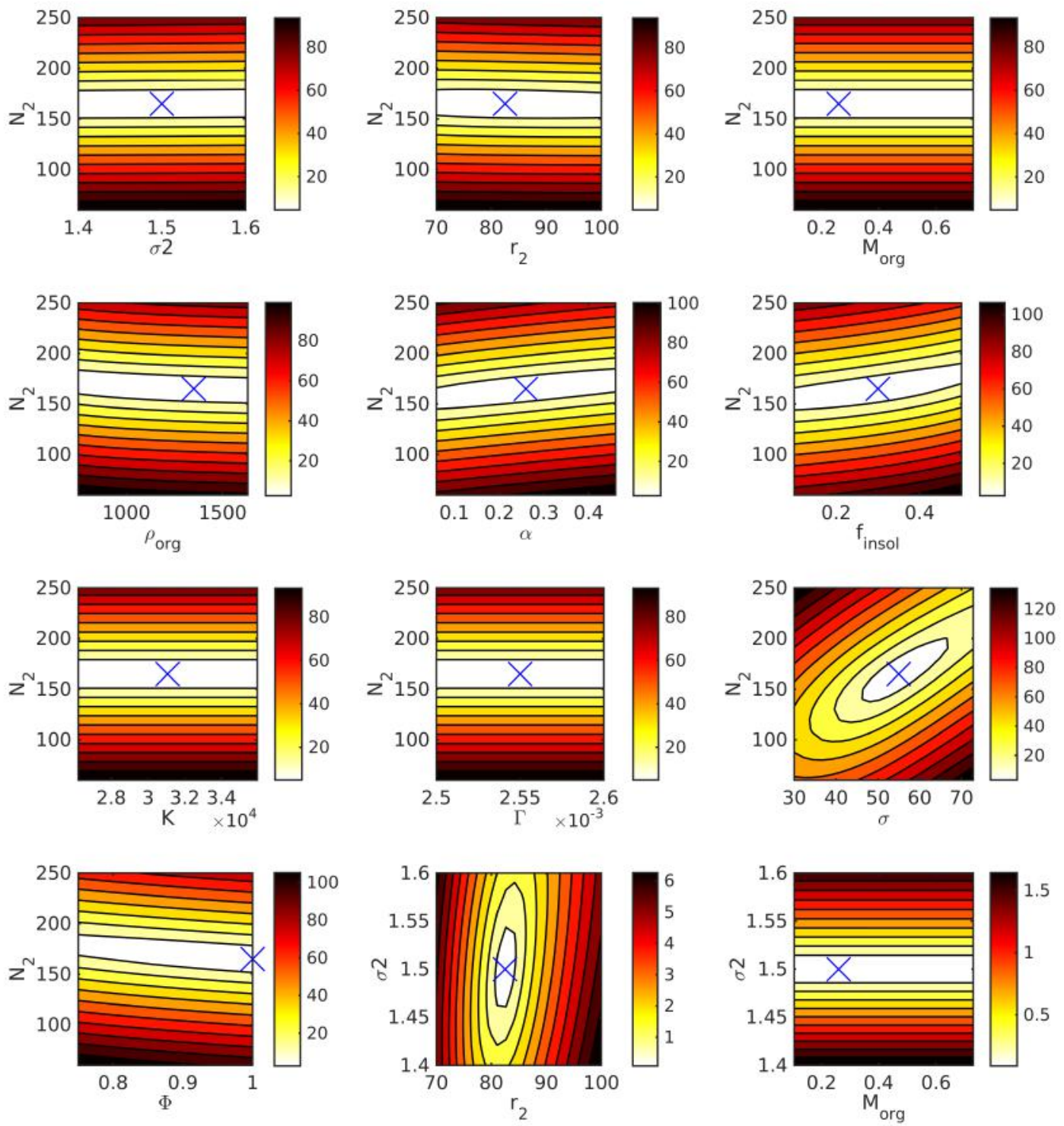

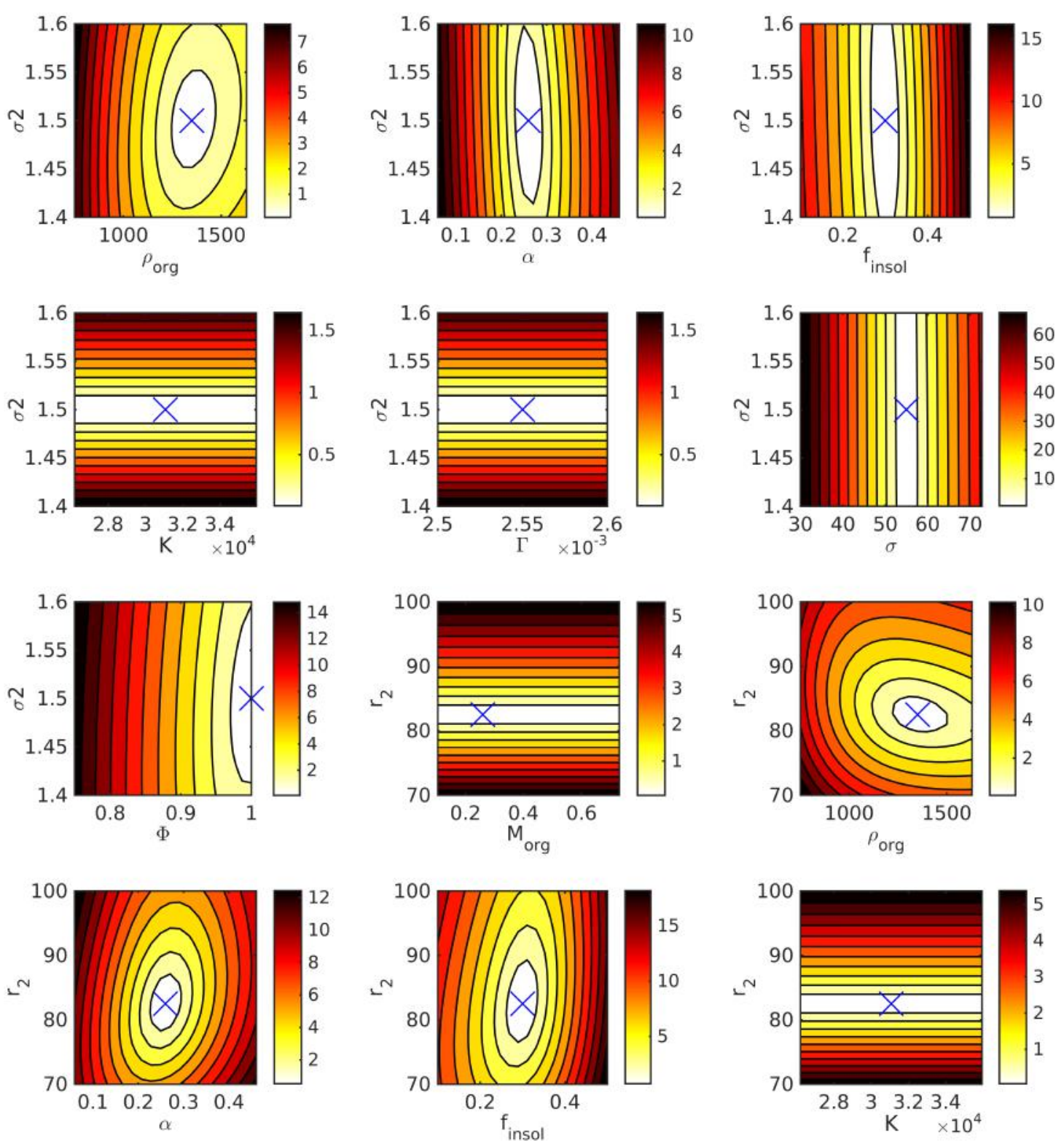

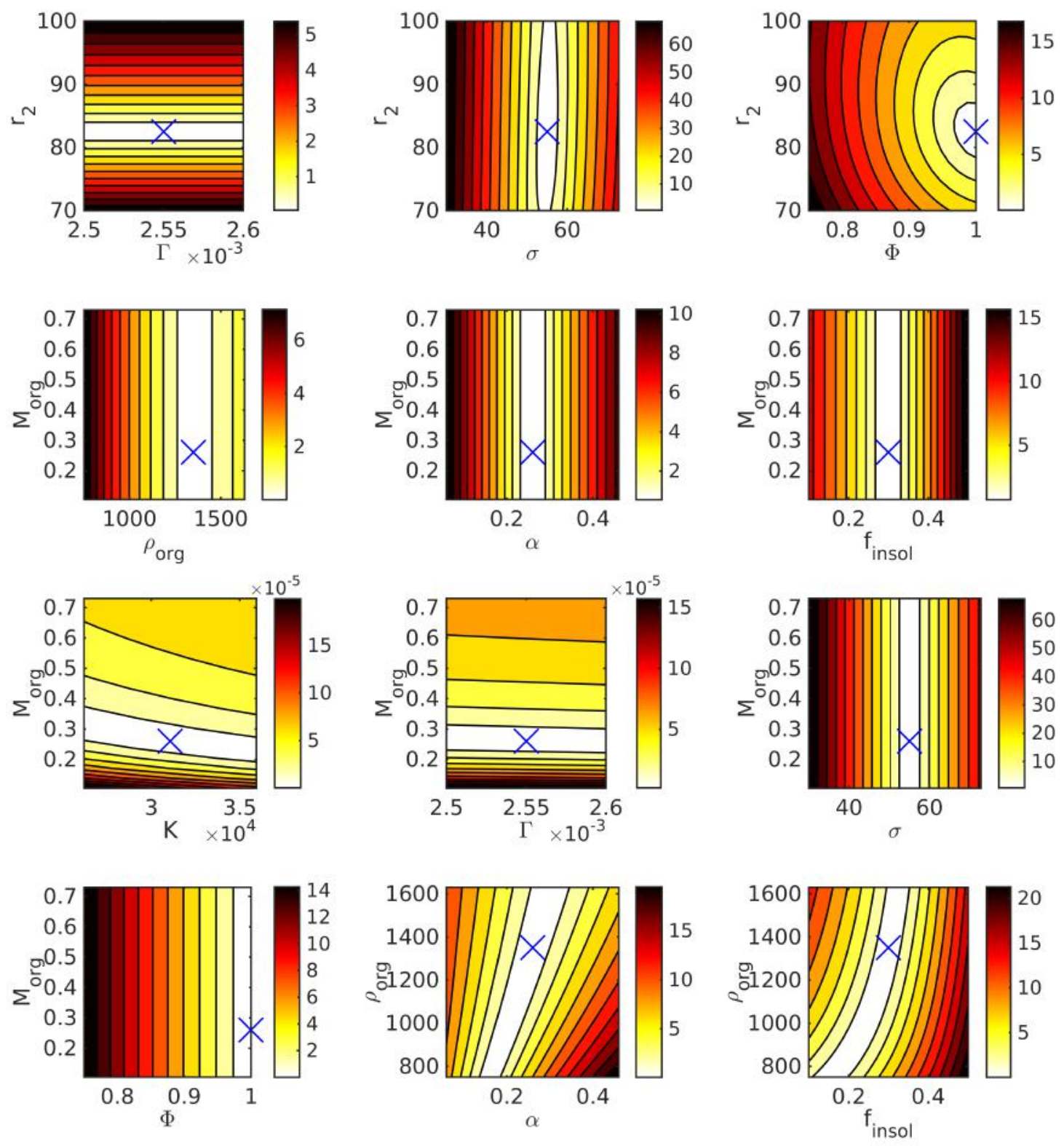

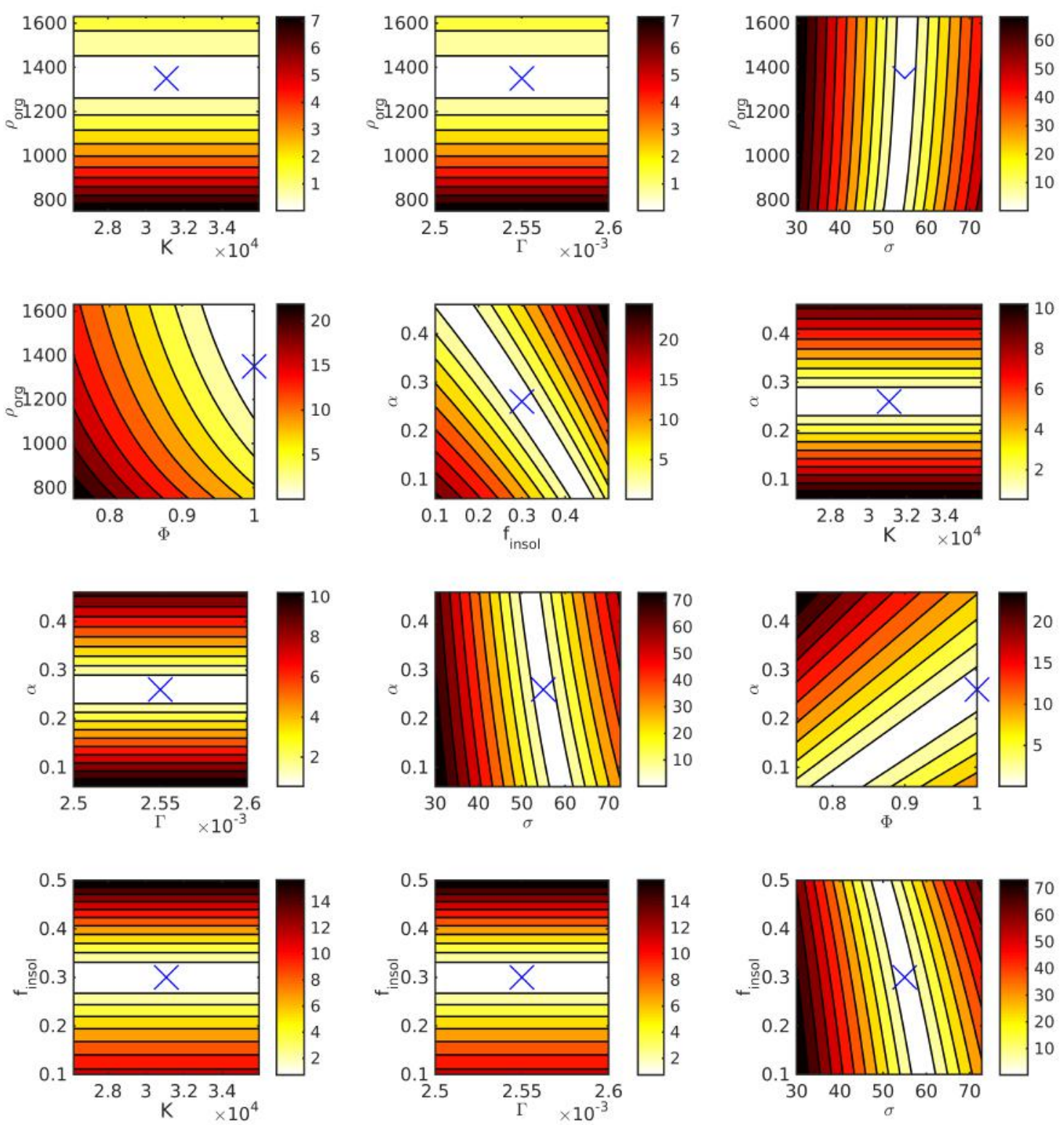

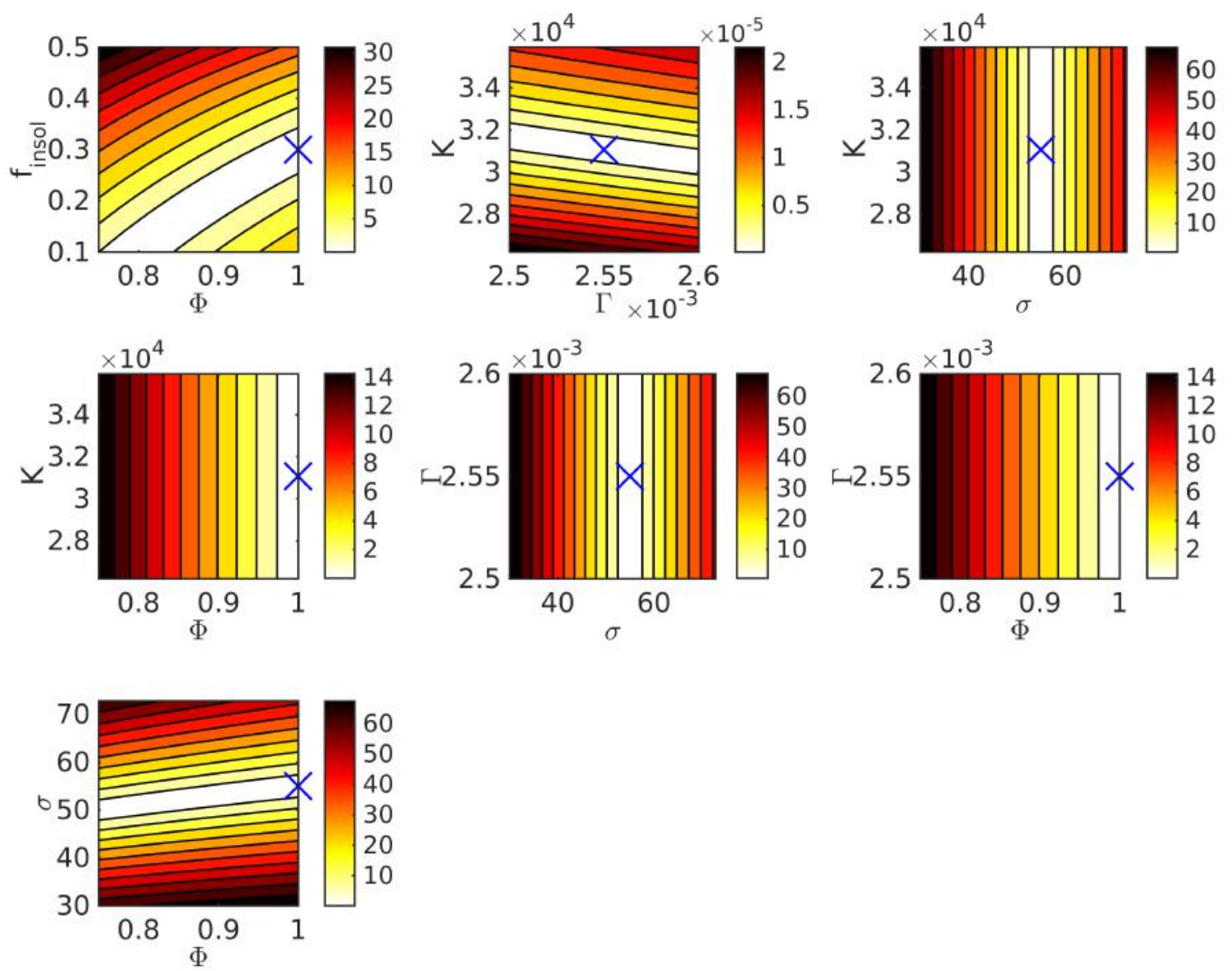

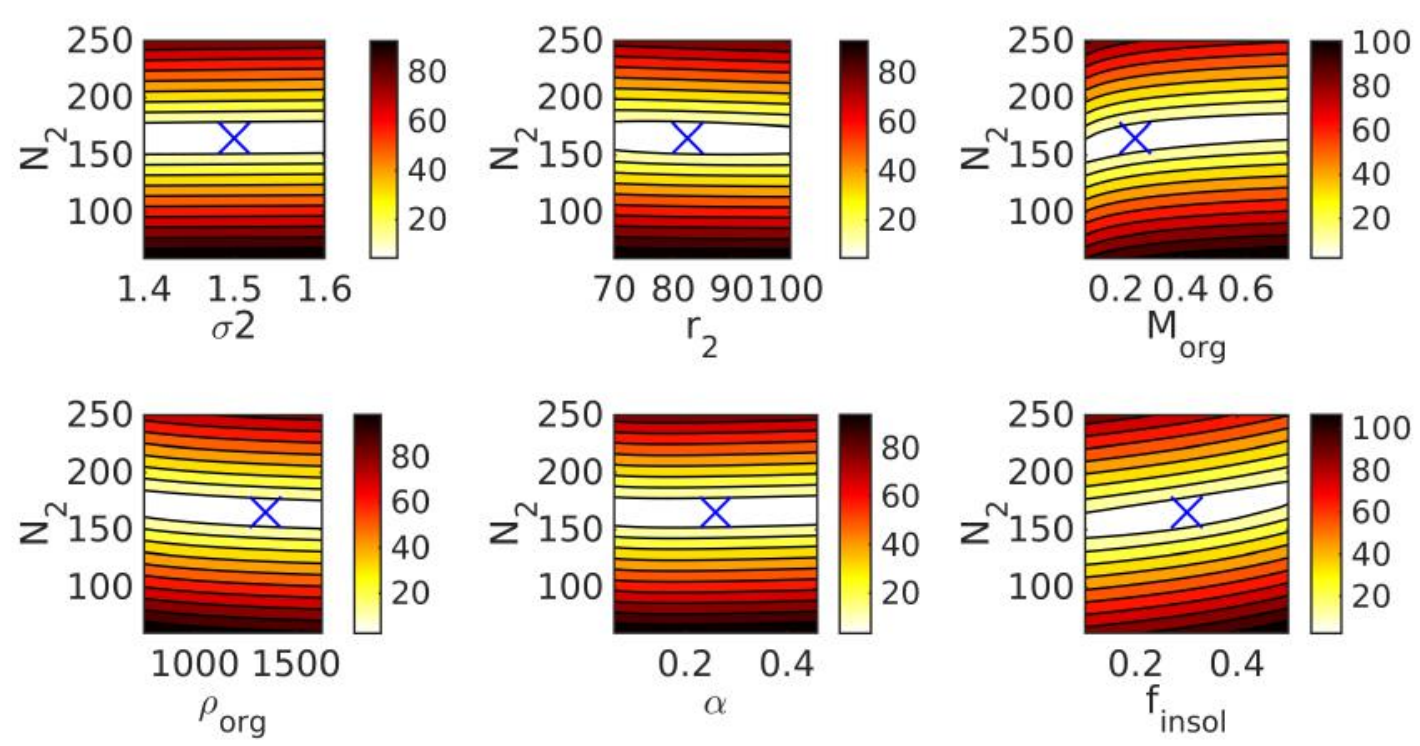

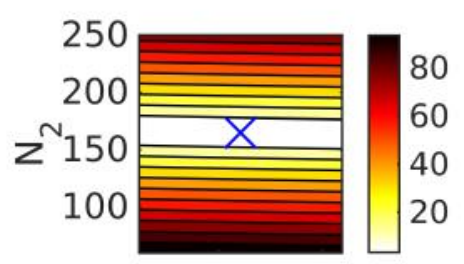

$$
3 \begin{array}{r}
3.5 \\
K \times 10^{4}
\end{array}
$$

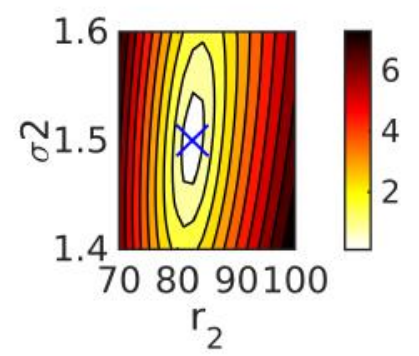

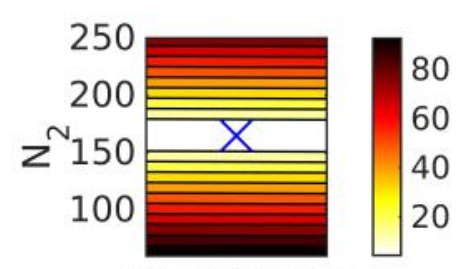

$\begin{array}{lll}2.5 & 2.55 \quad 2.6\end{array}$

ए $10^{-3}$

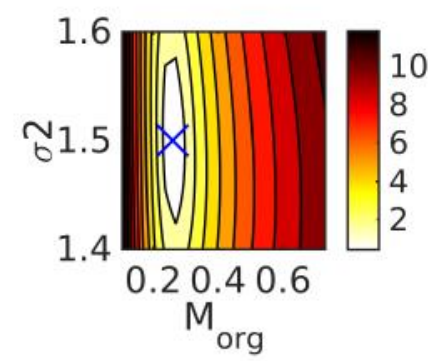

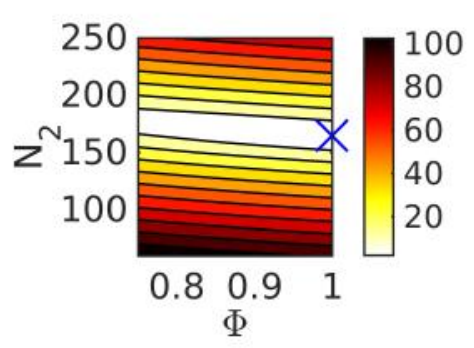

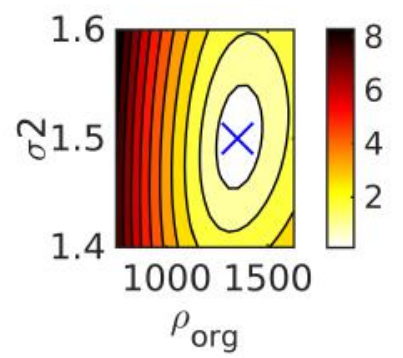



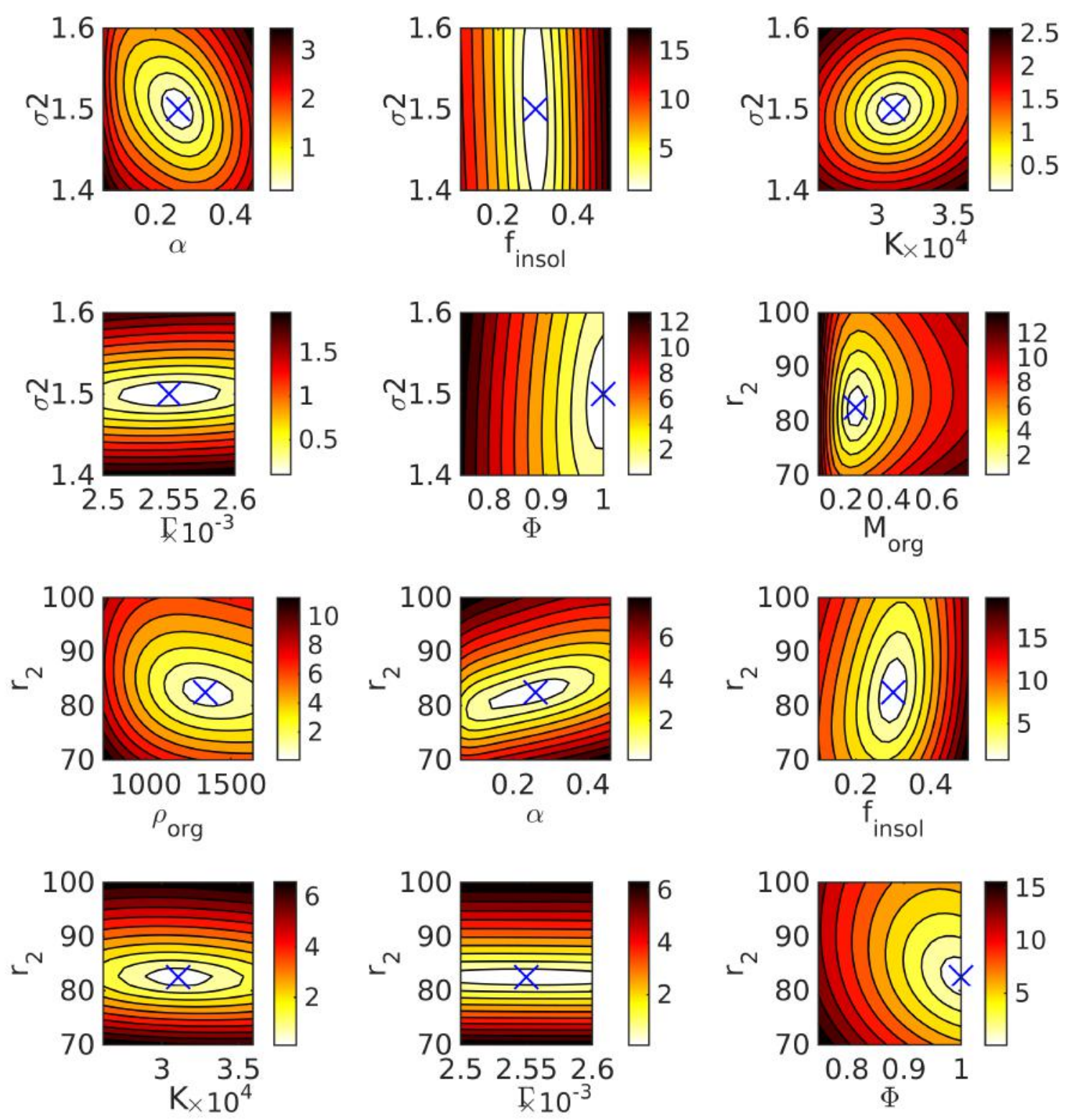

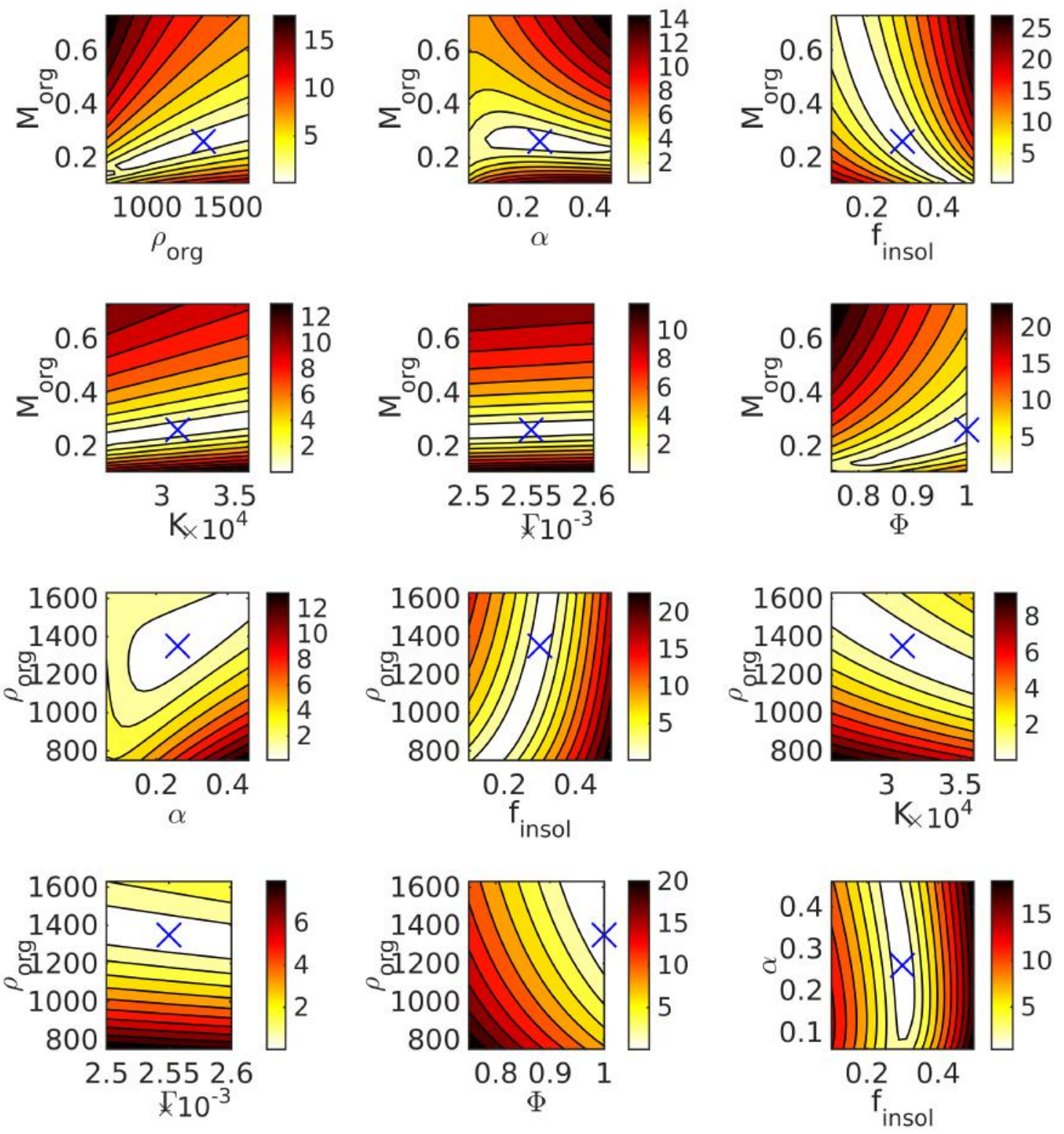

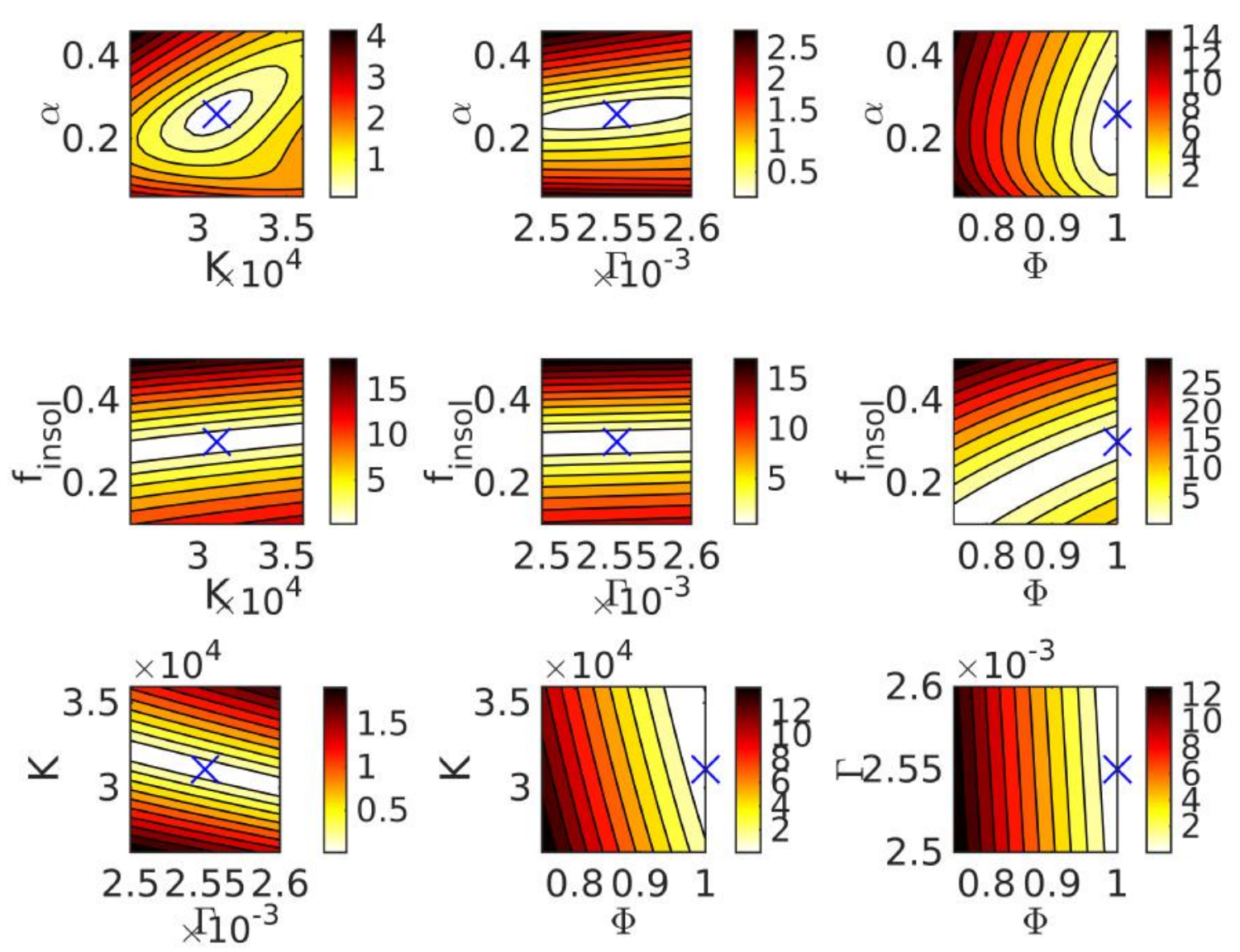


\subsubsection{Case 4: $a_{w}^{p} \sigma^{n f}$}
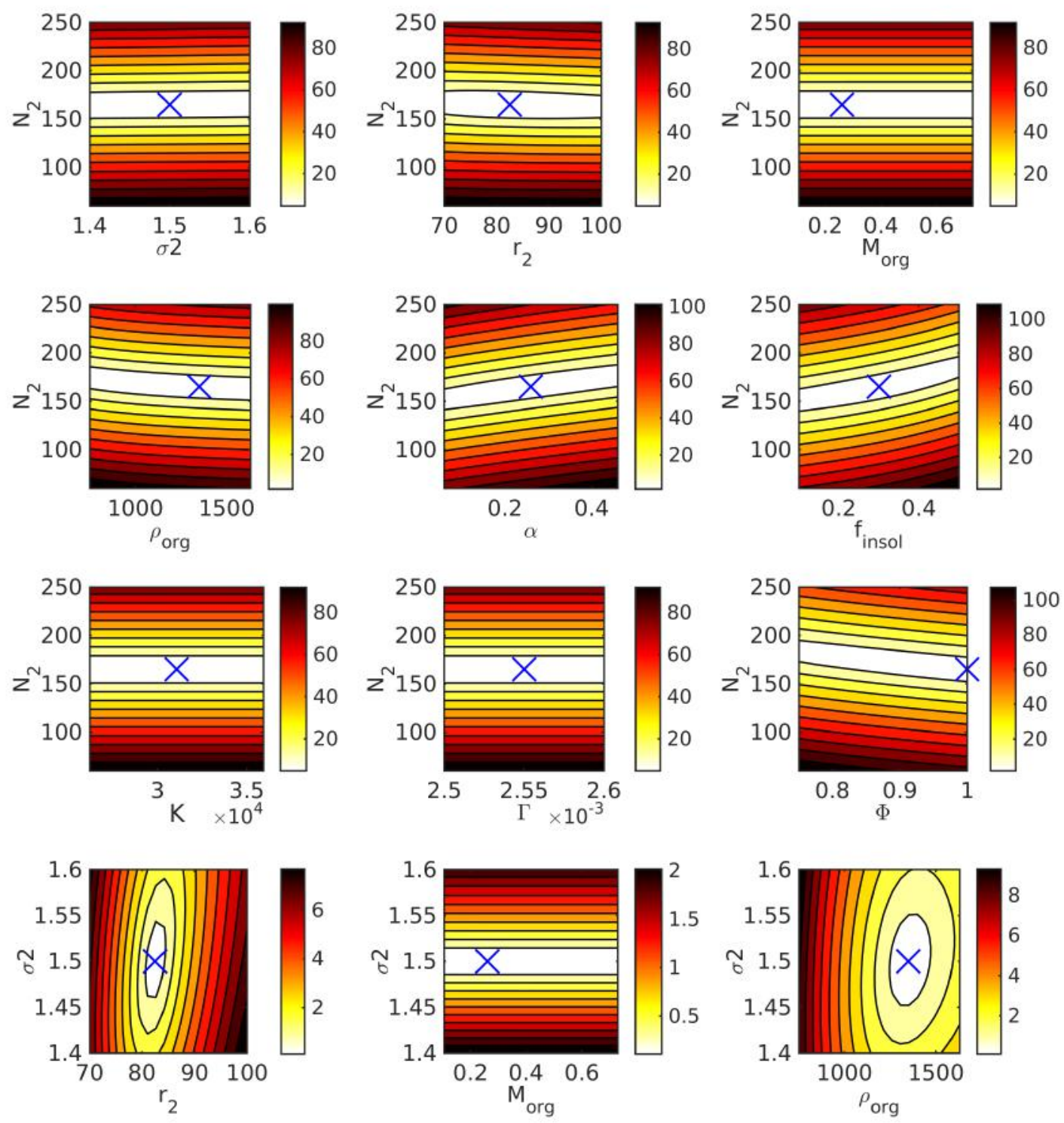

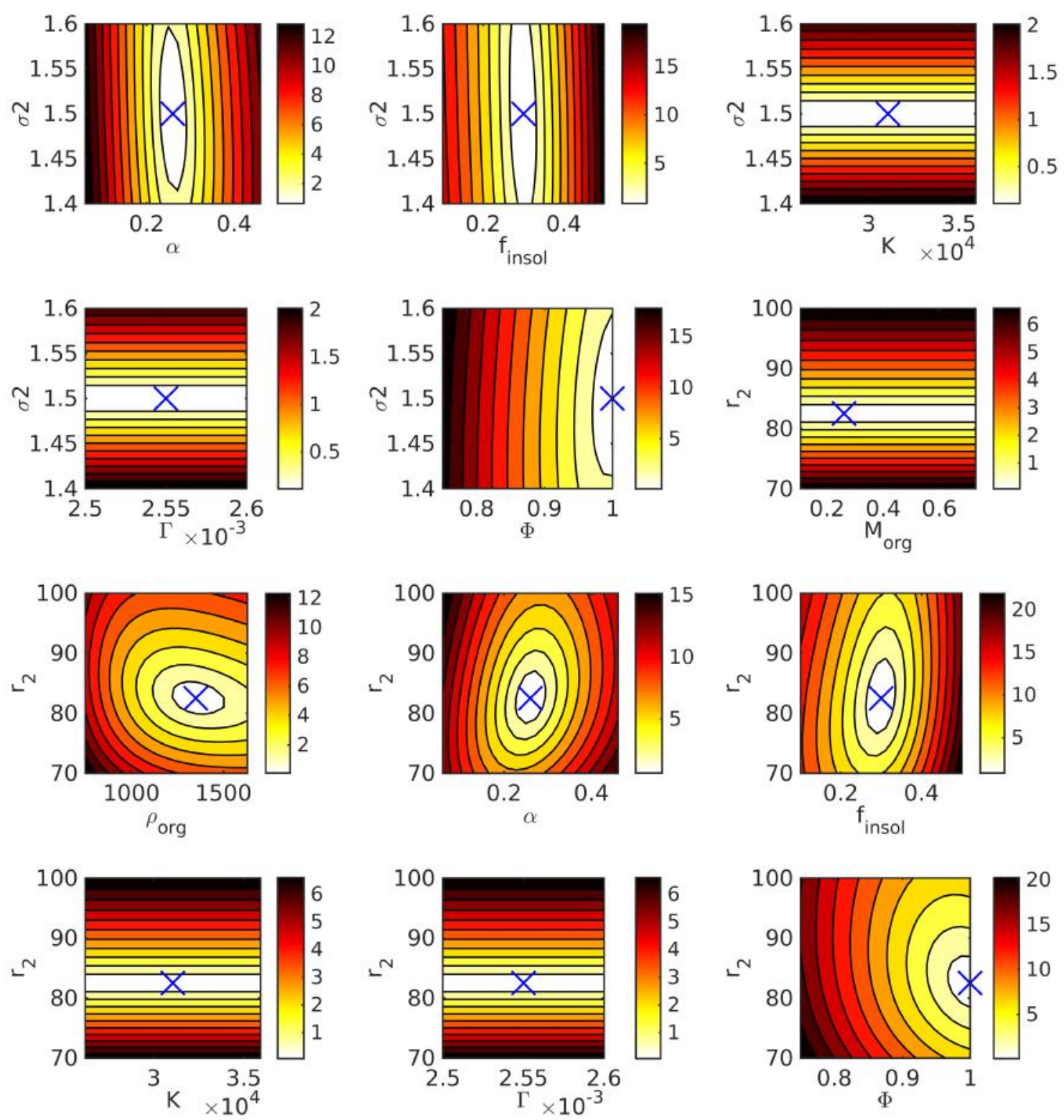

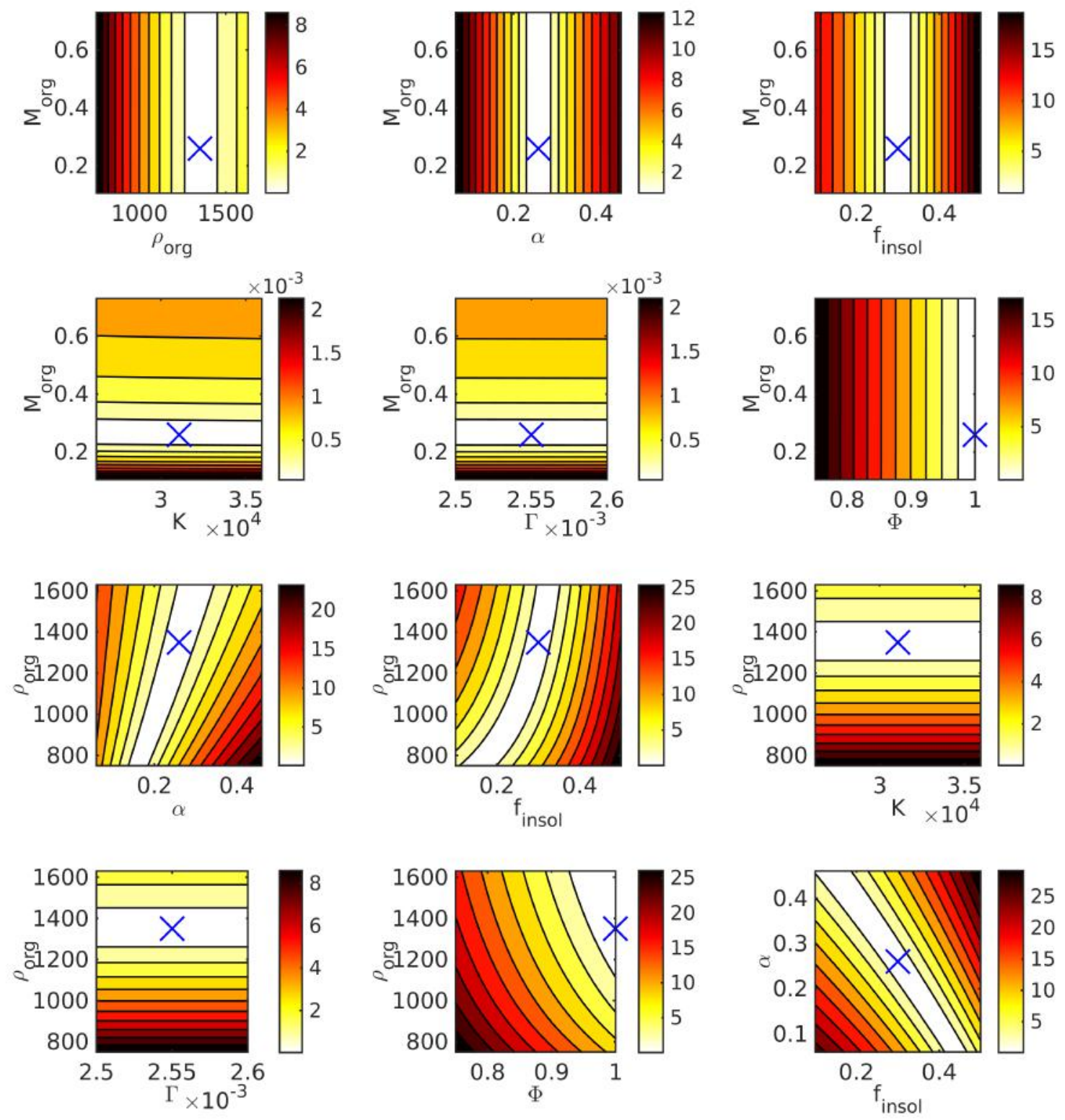

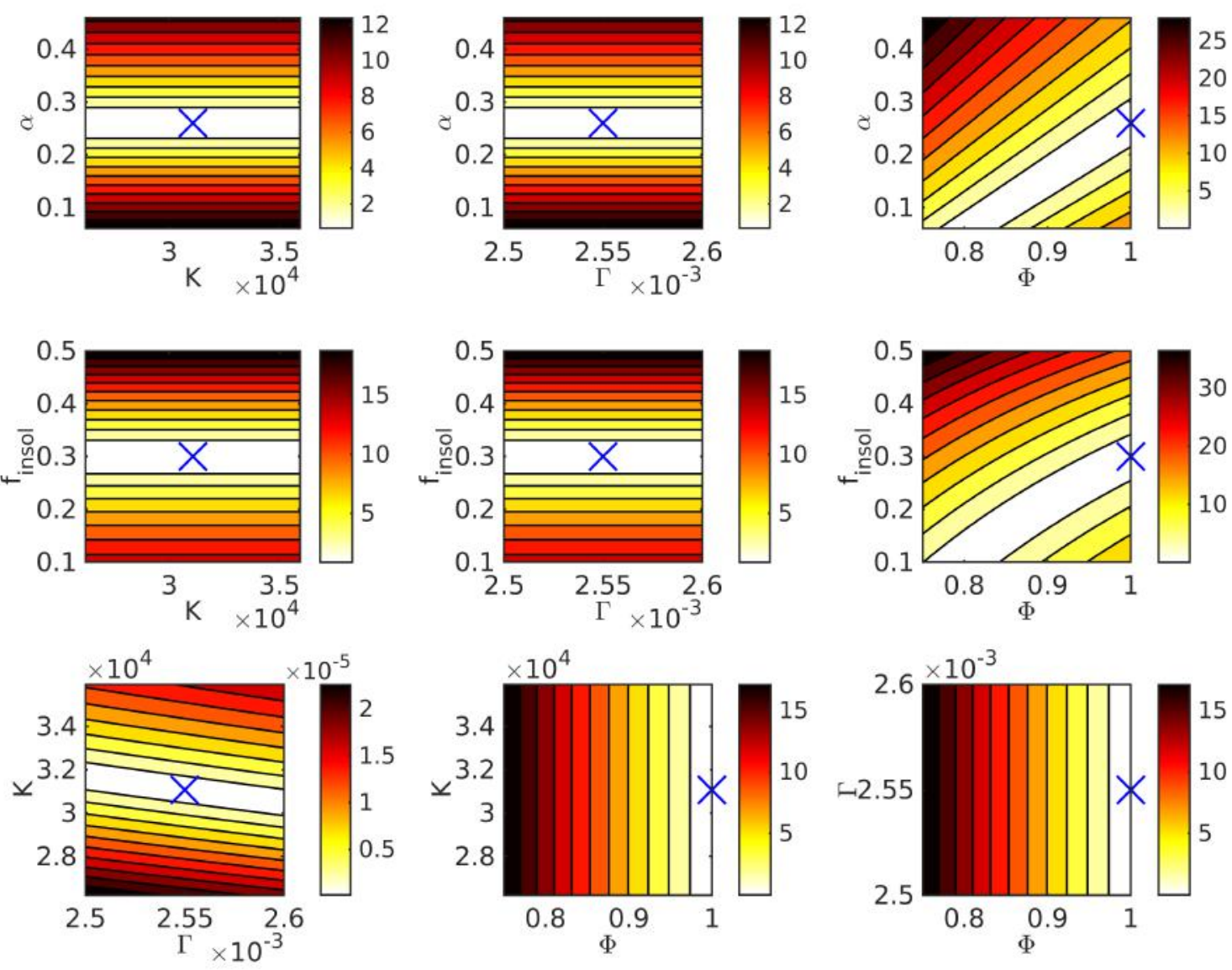


\subsection{Rural continental}

\subsubsection{Case 1: $a_{w}^{n p} \sigma^{f}$}
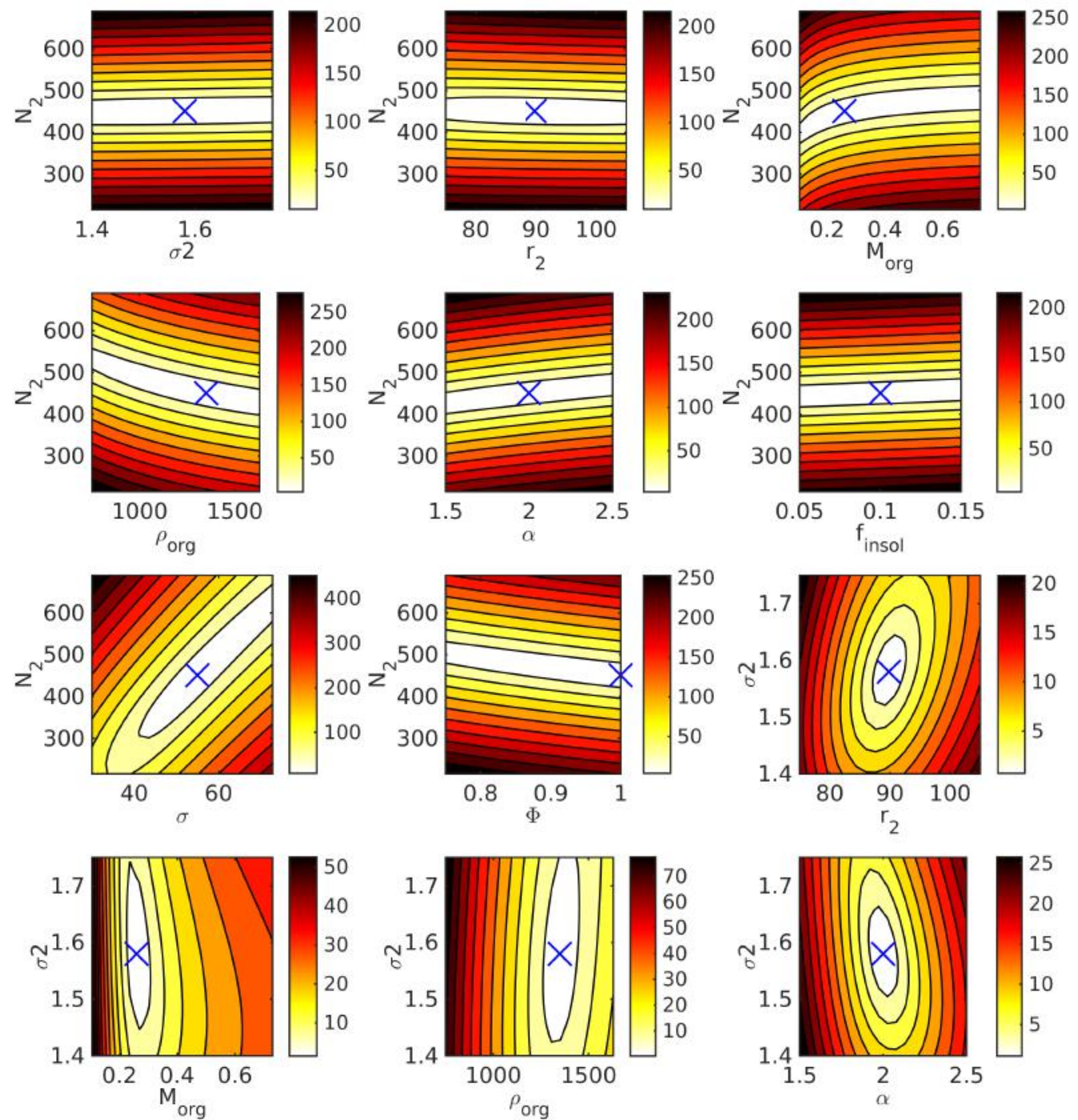

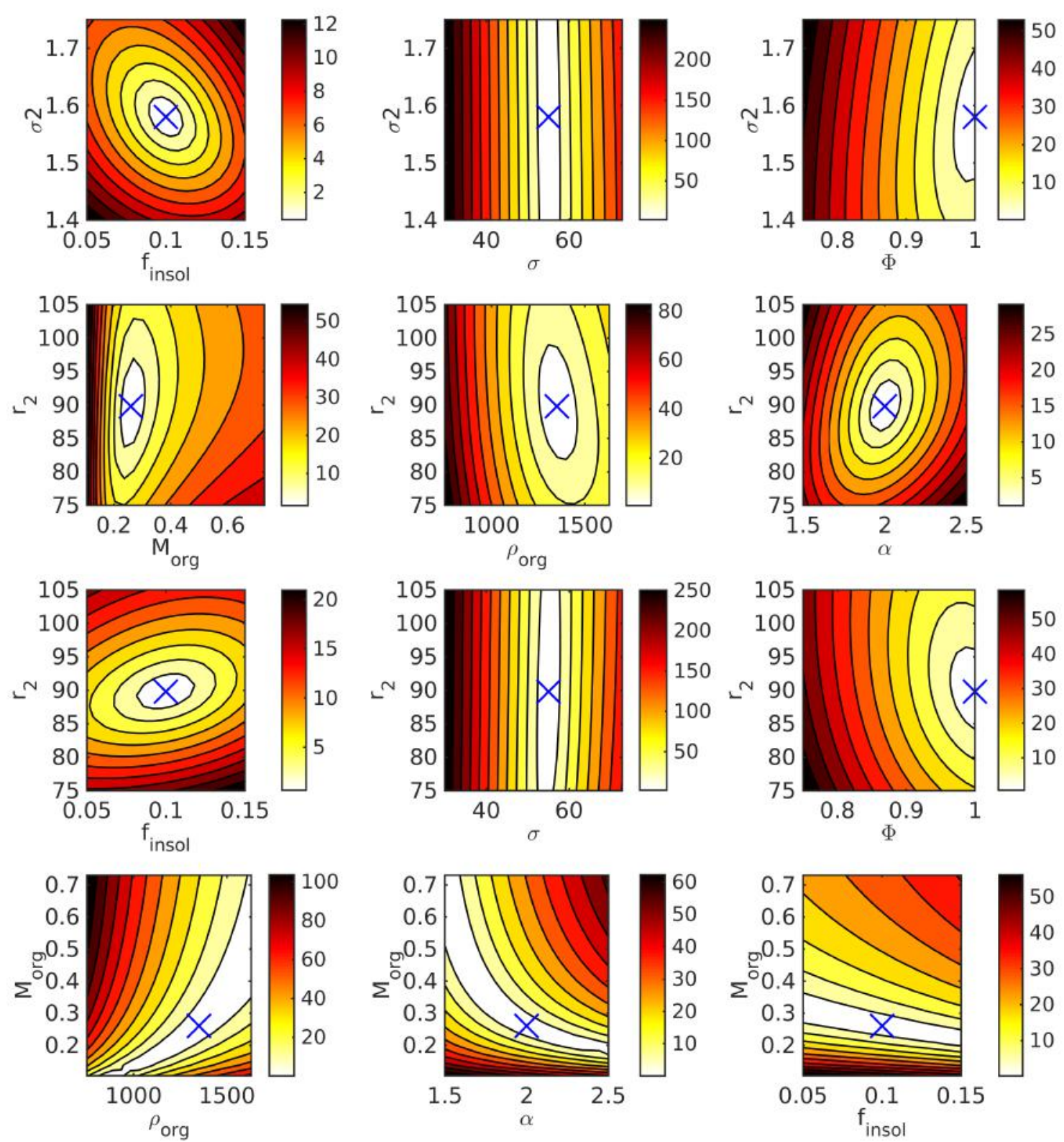

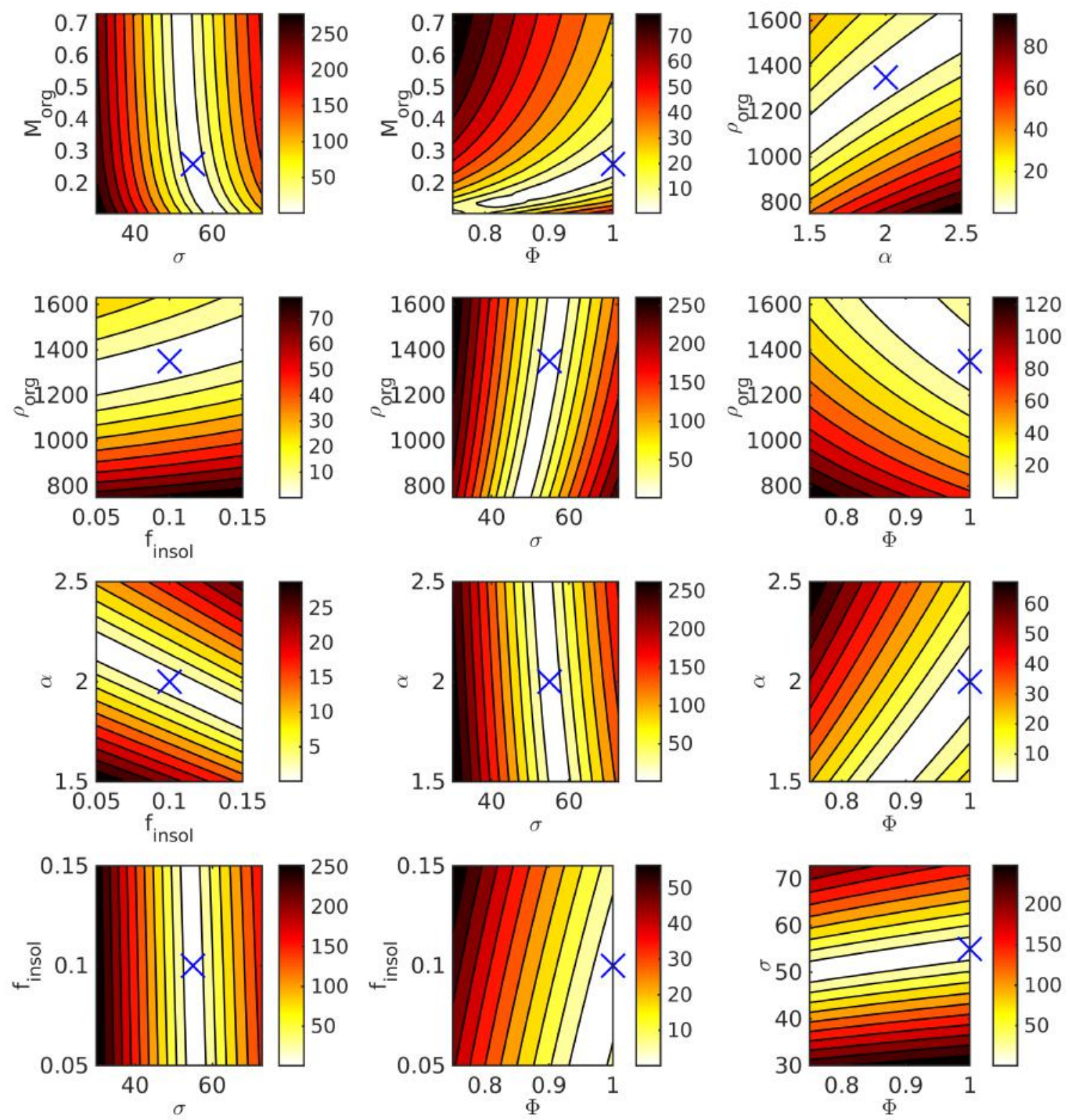


\subsubsection{Case 2: $a_{w}^{p} \sigma^{f}$}
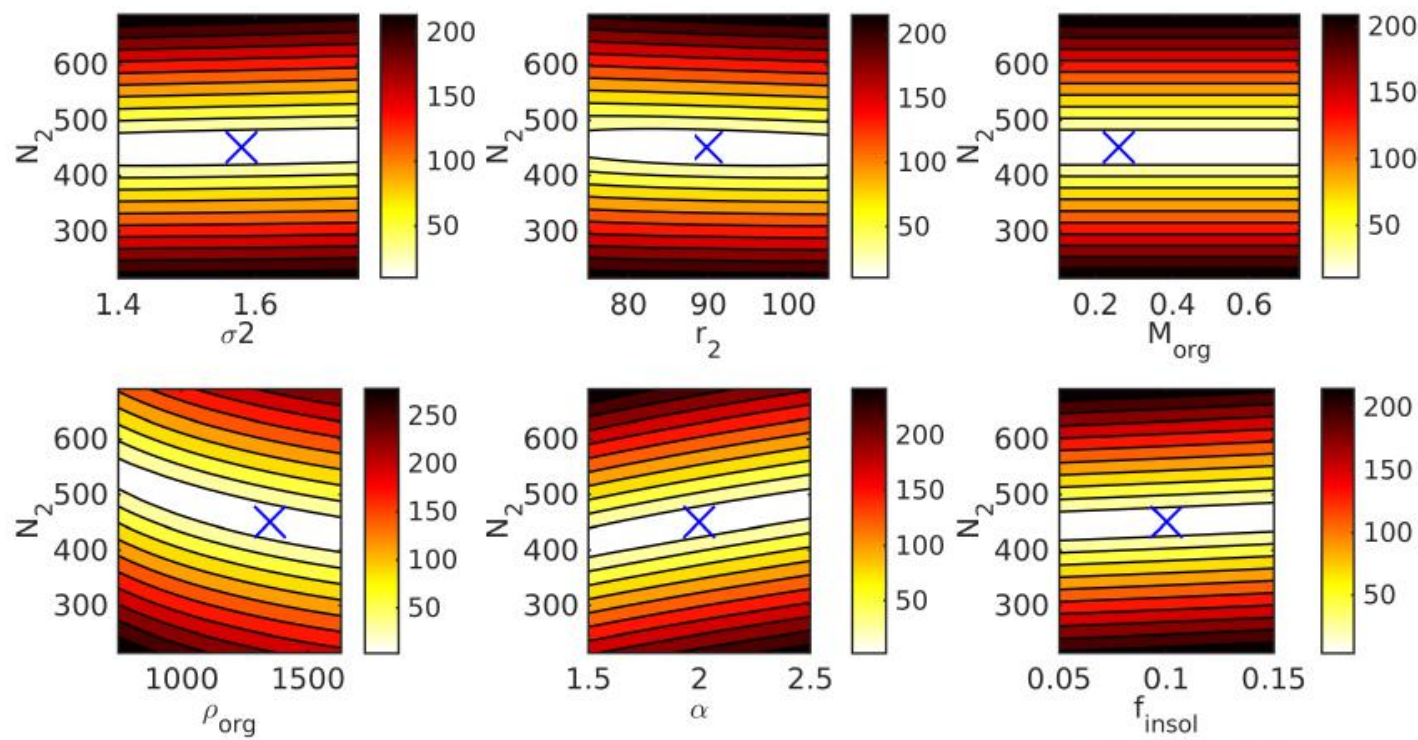

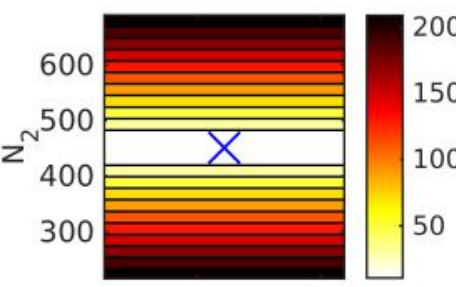

3.5
$\mathrm{~K} \quad \times 10^{4}$

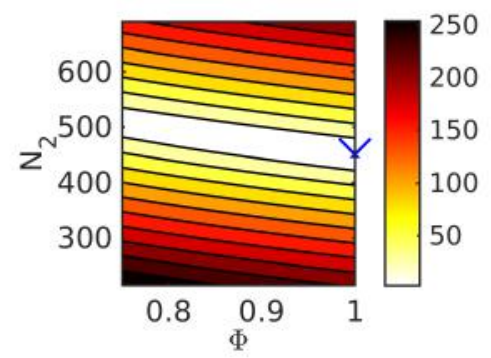

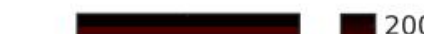

$$
600
$$

$2^{500}$ 300
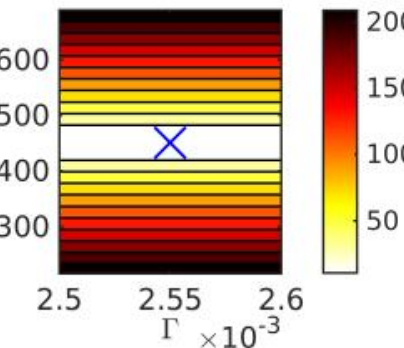

$0.05 \underset{\substack{0.1 \\ f_{\text {insol }}}}{0.1} 0.15$

150

100

50 

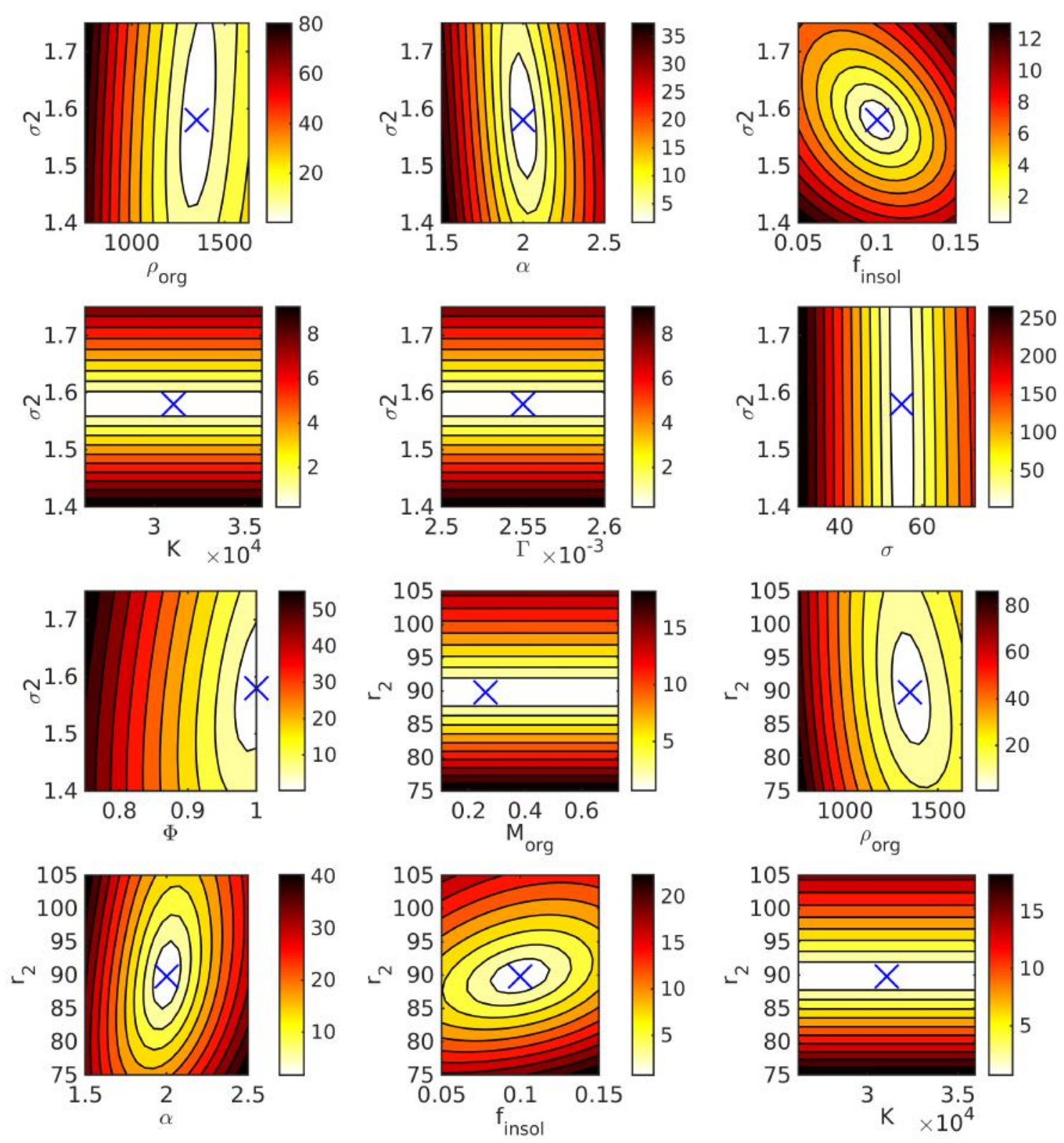

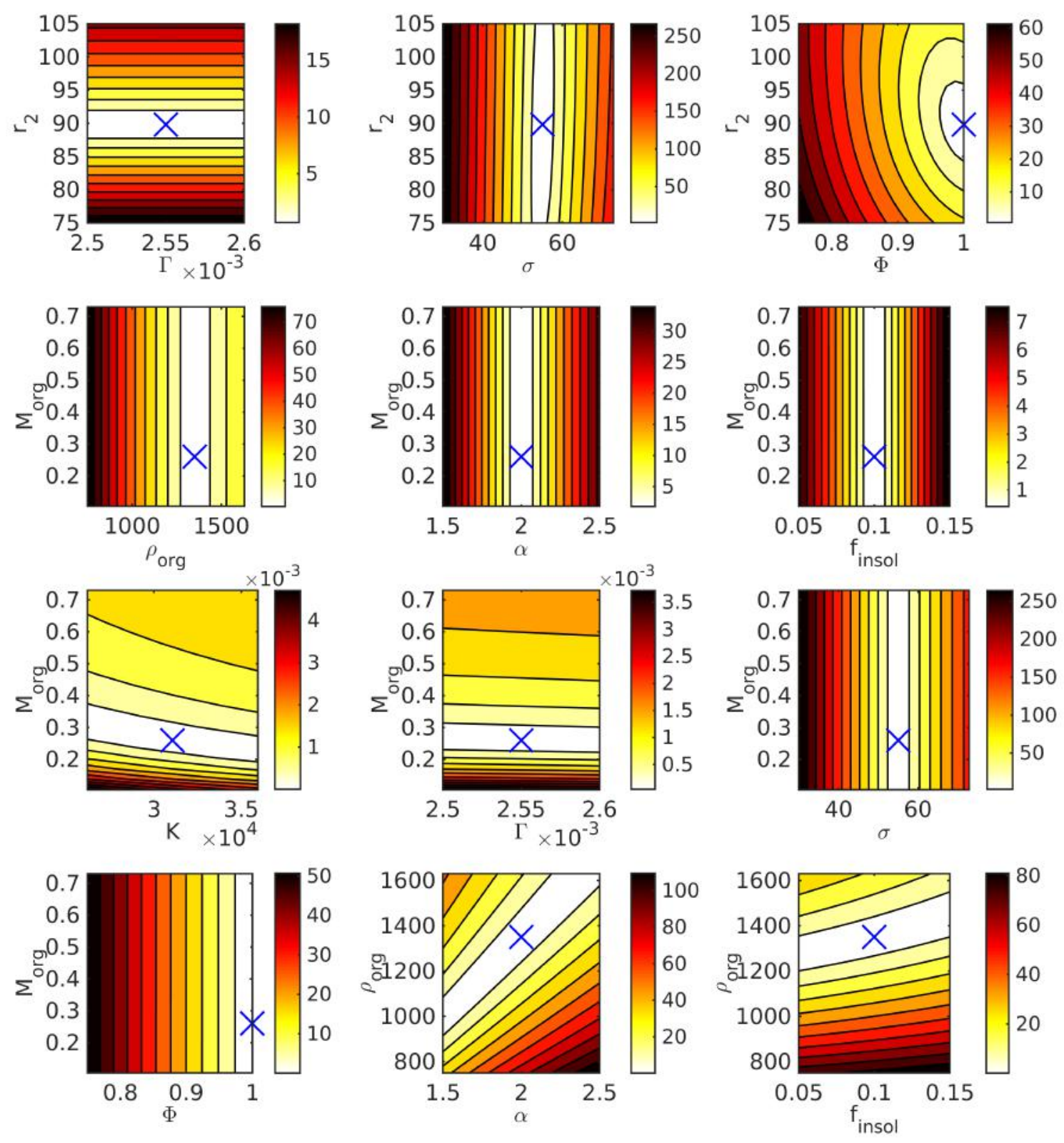

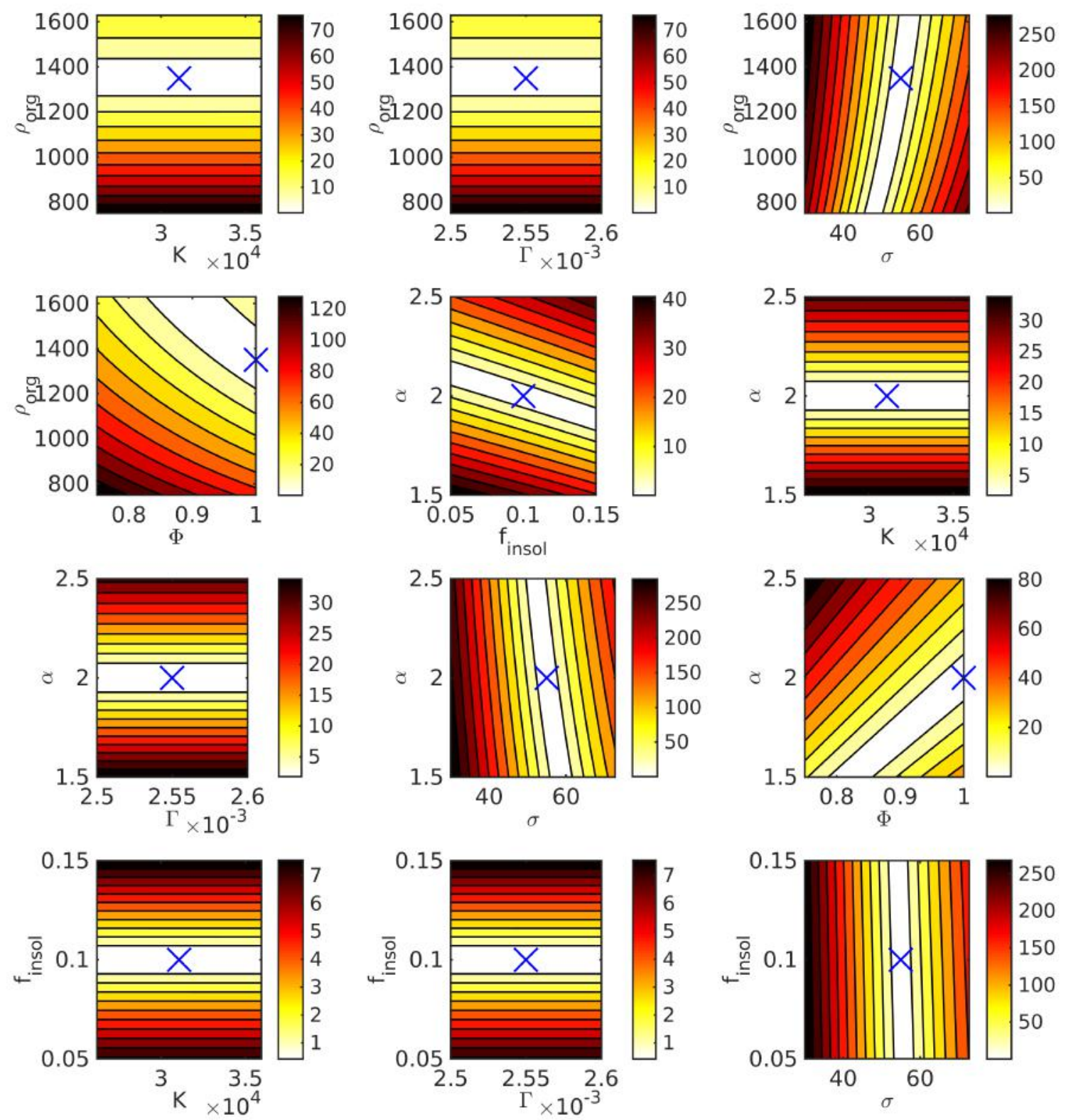

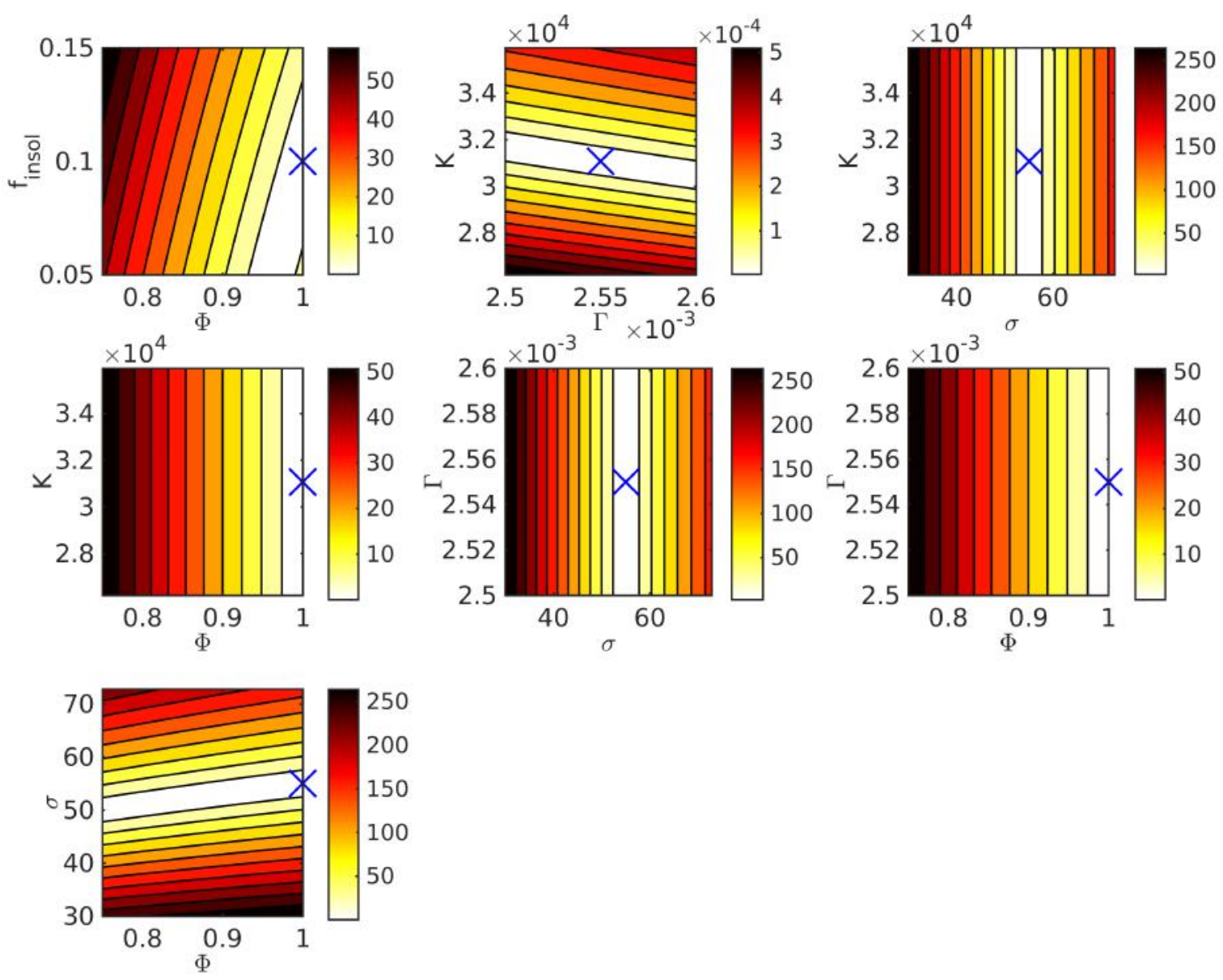

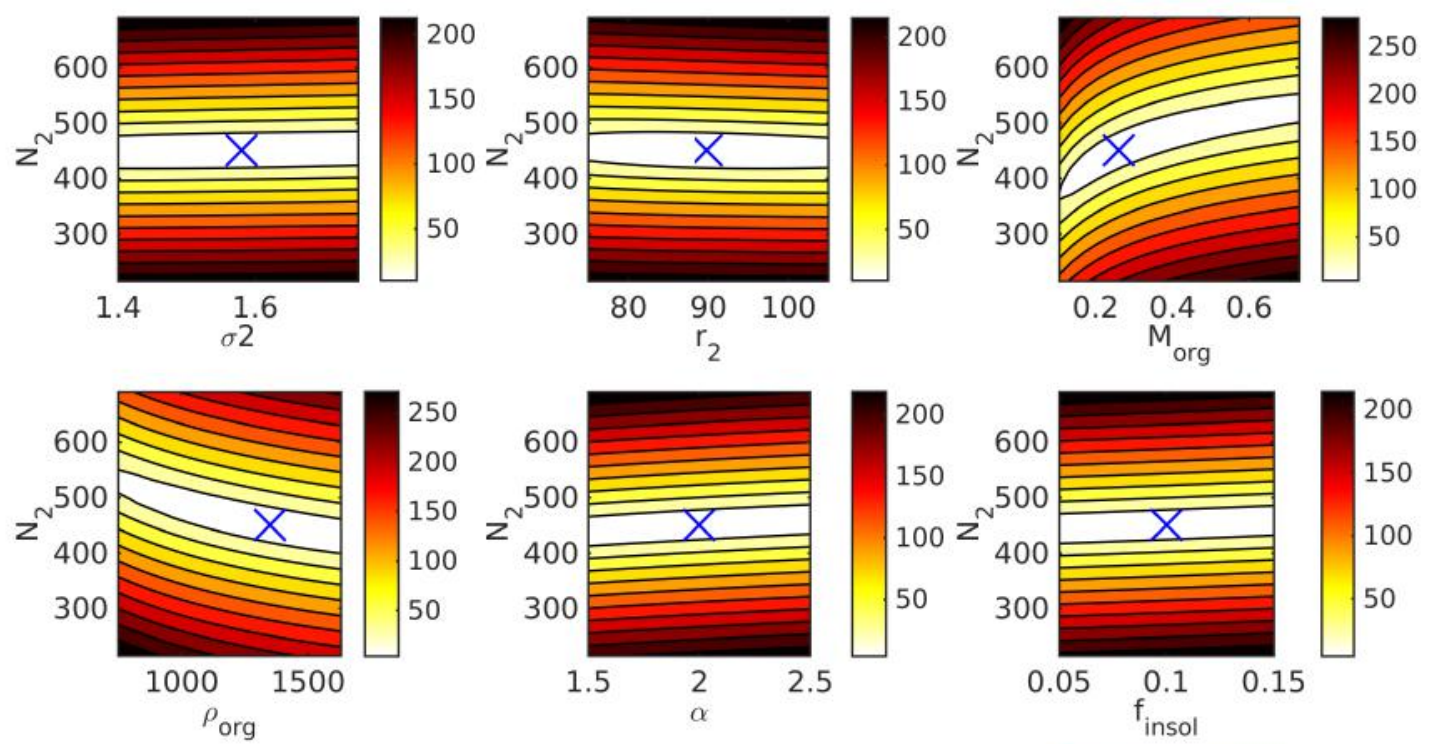

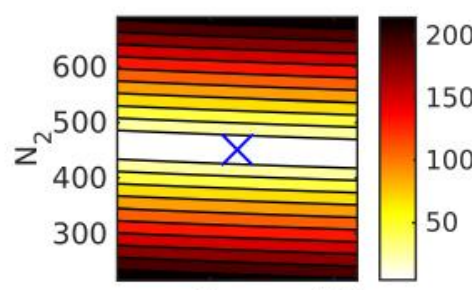

${ }^{3} \mathrm{~K} \begin{array}{r}3.5 \\ \times 10^{4}\end{array}$

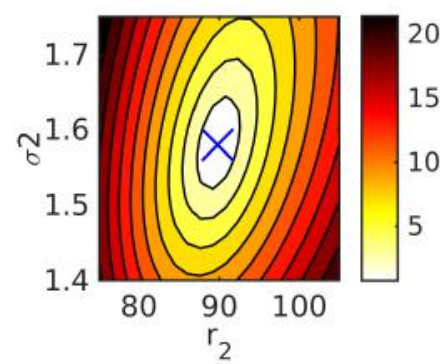

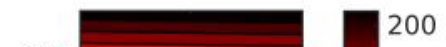

600 $0 z^{n^{500}}$

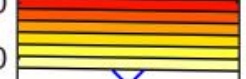
300
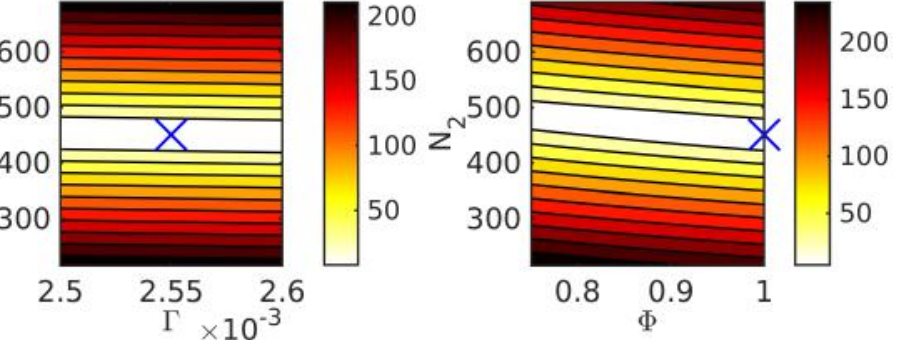

$0.8 \underset{\Phi}{0.9} 1$

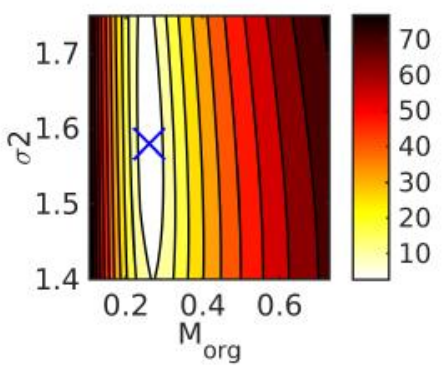



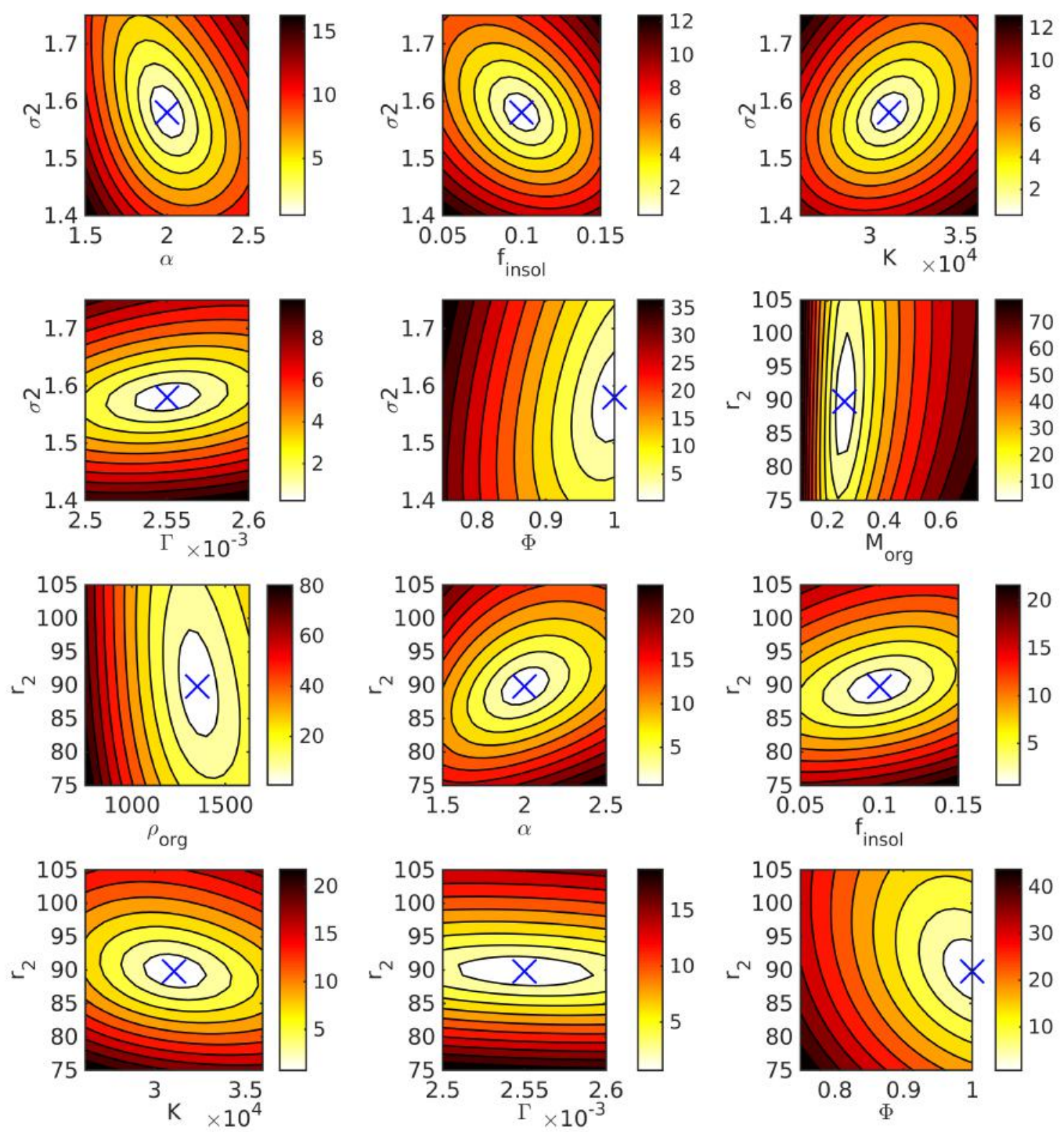

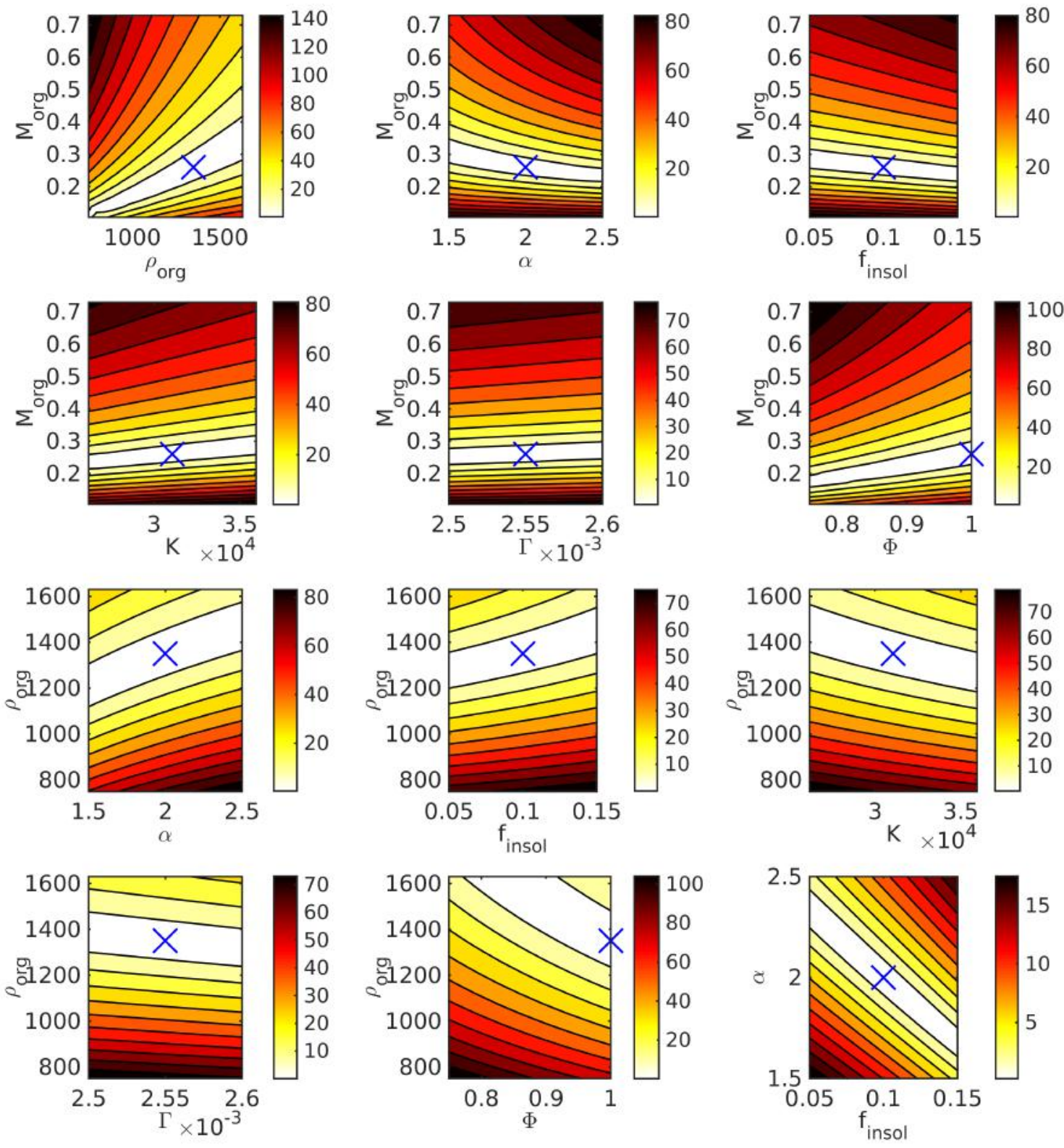

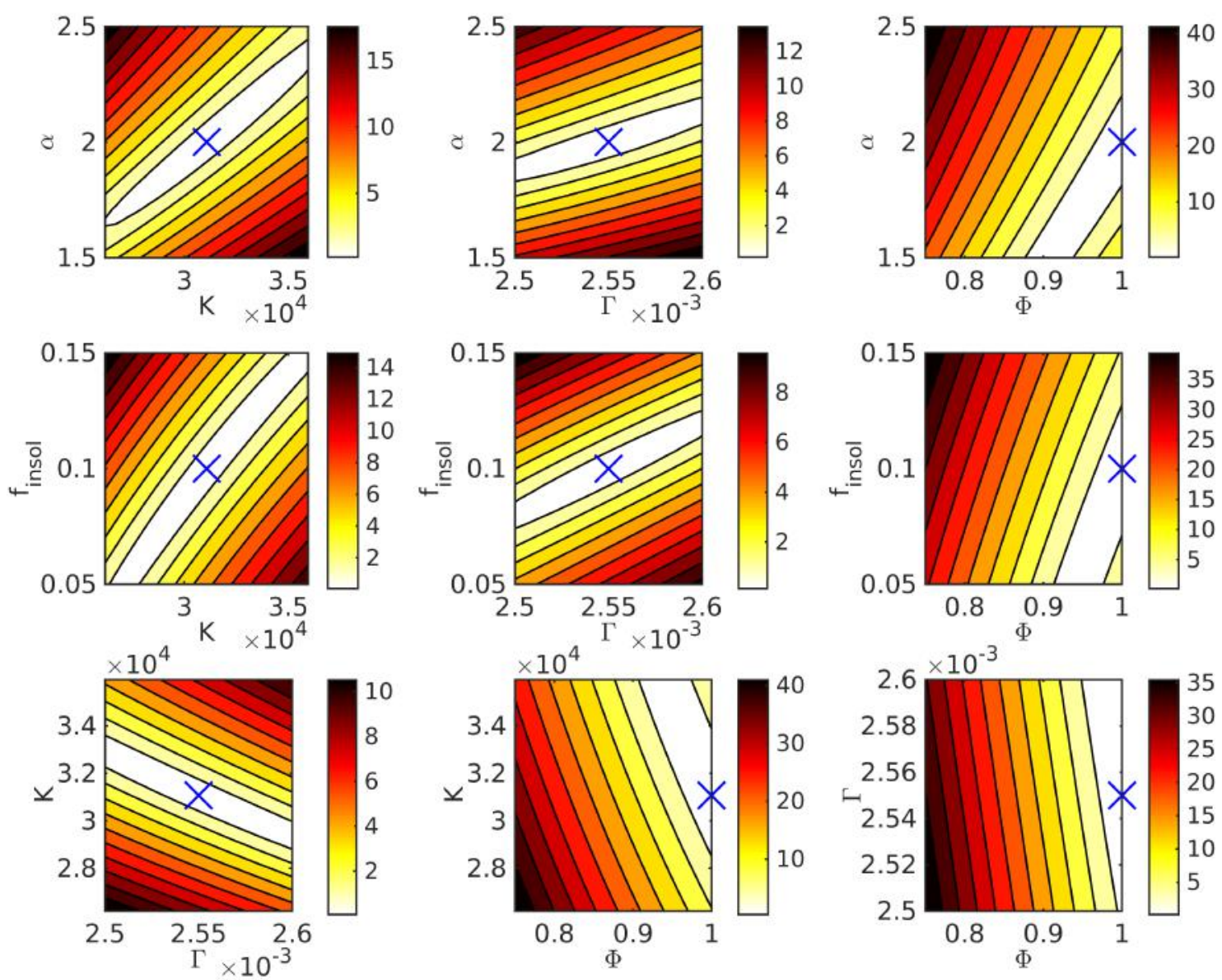

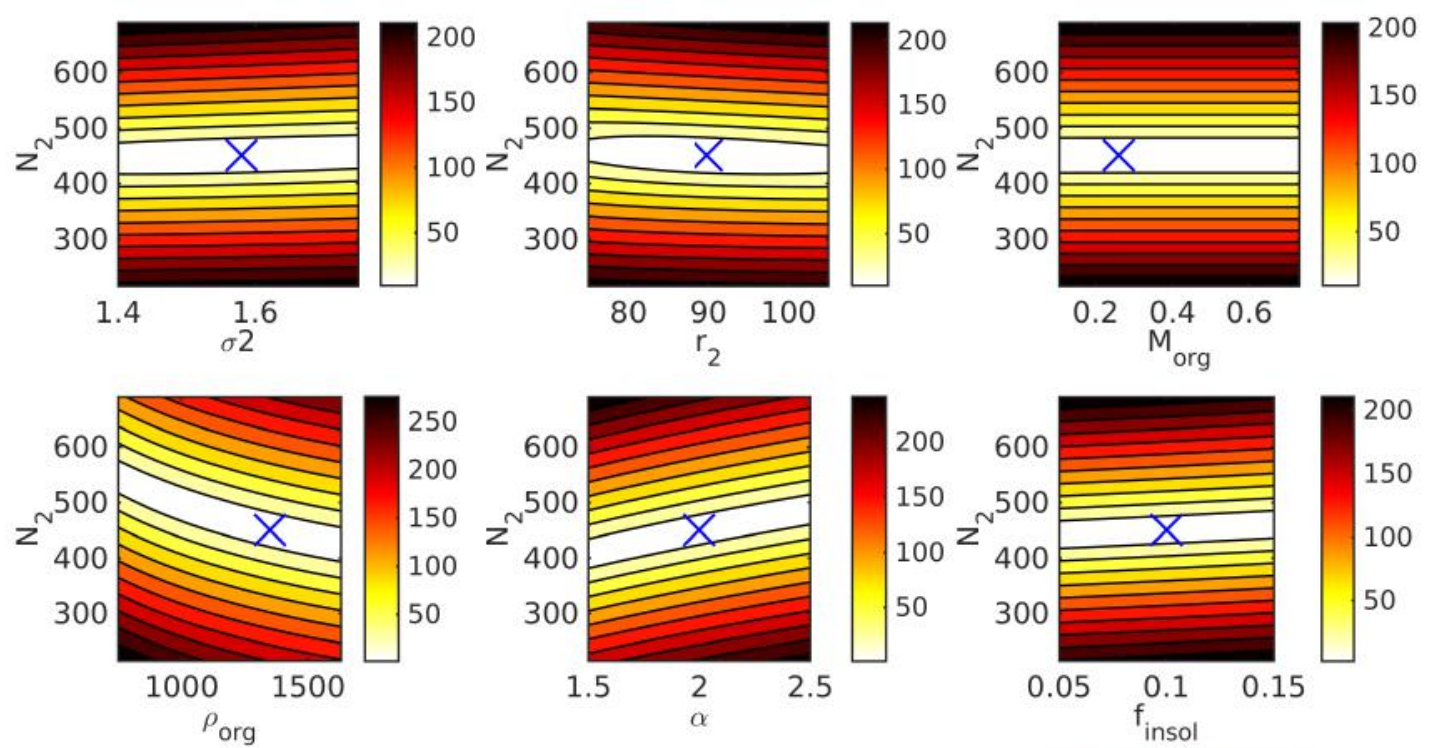

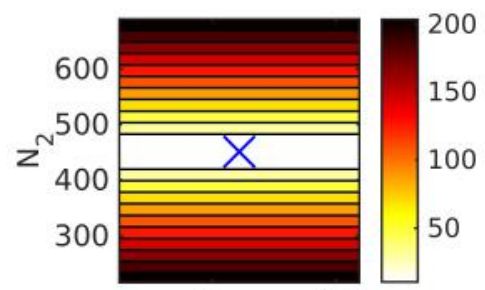

3.5
$\mathrm{~K} \quad \times 10^{4}$

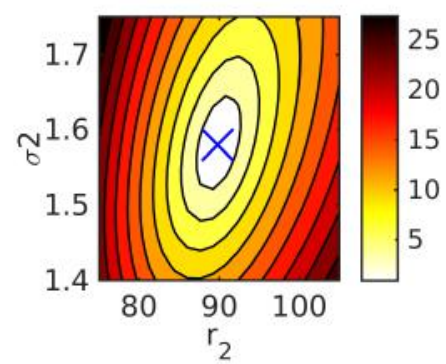

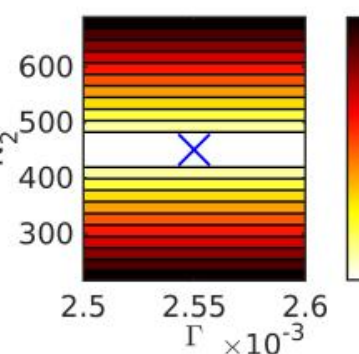
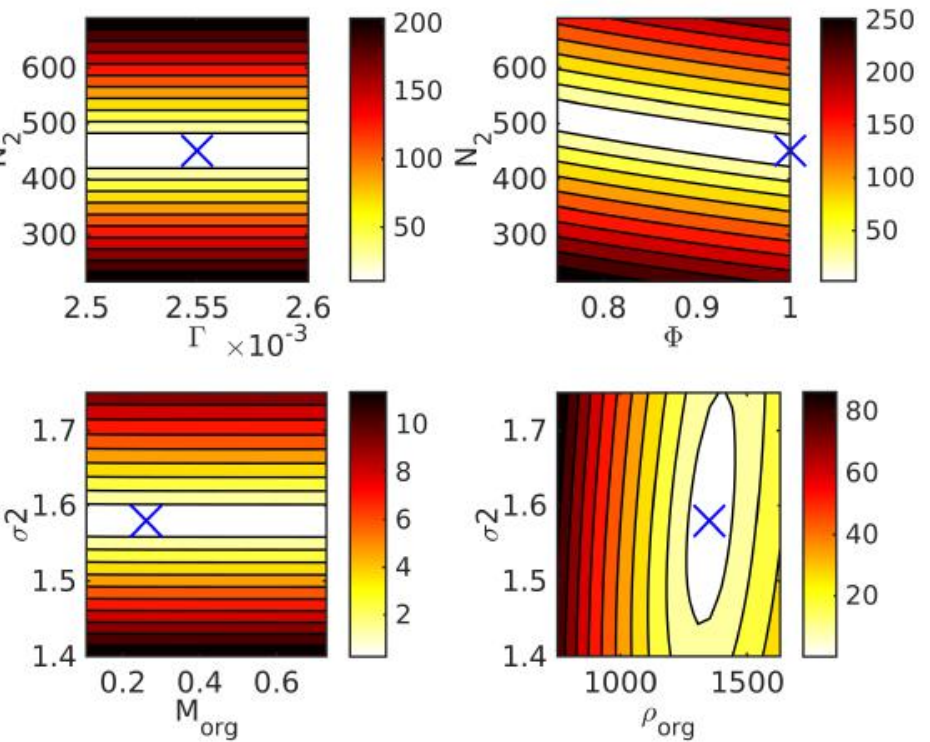

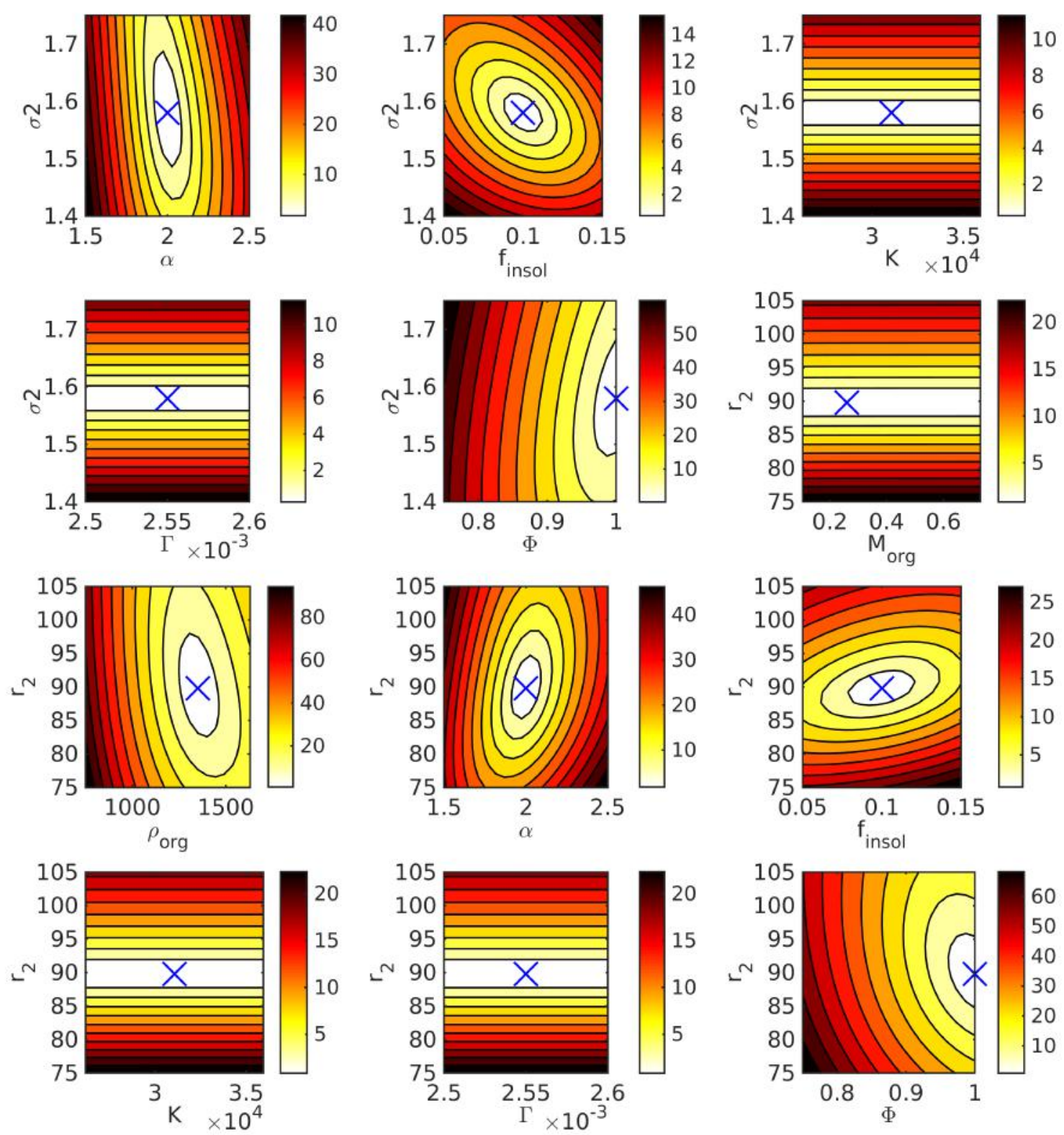

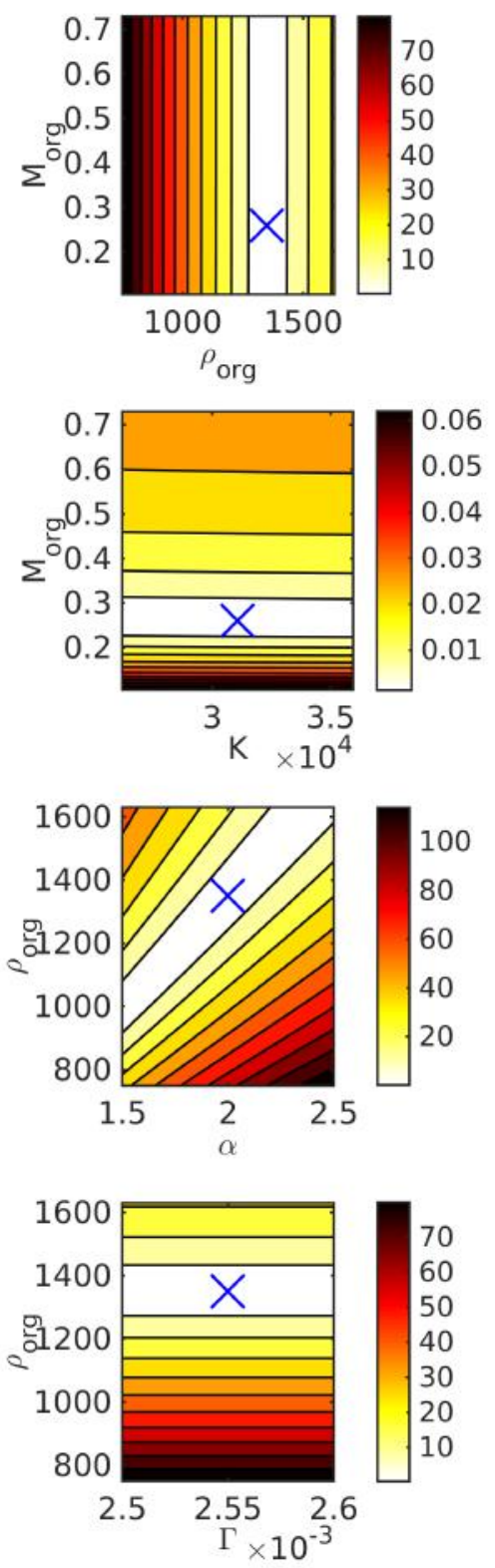
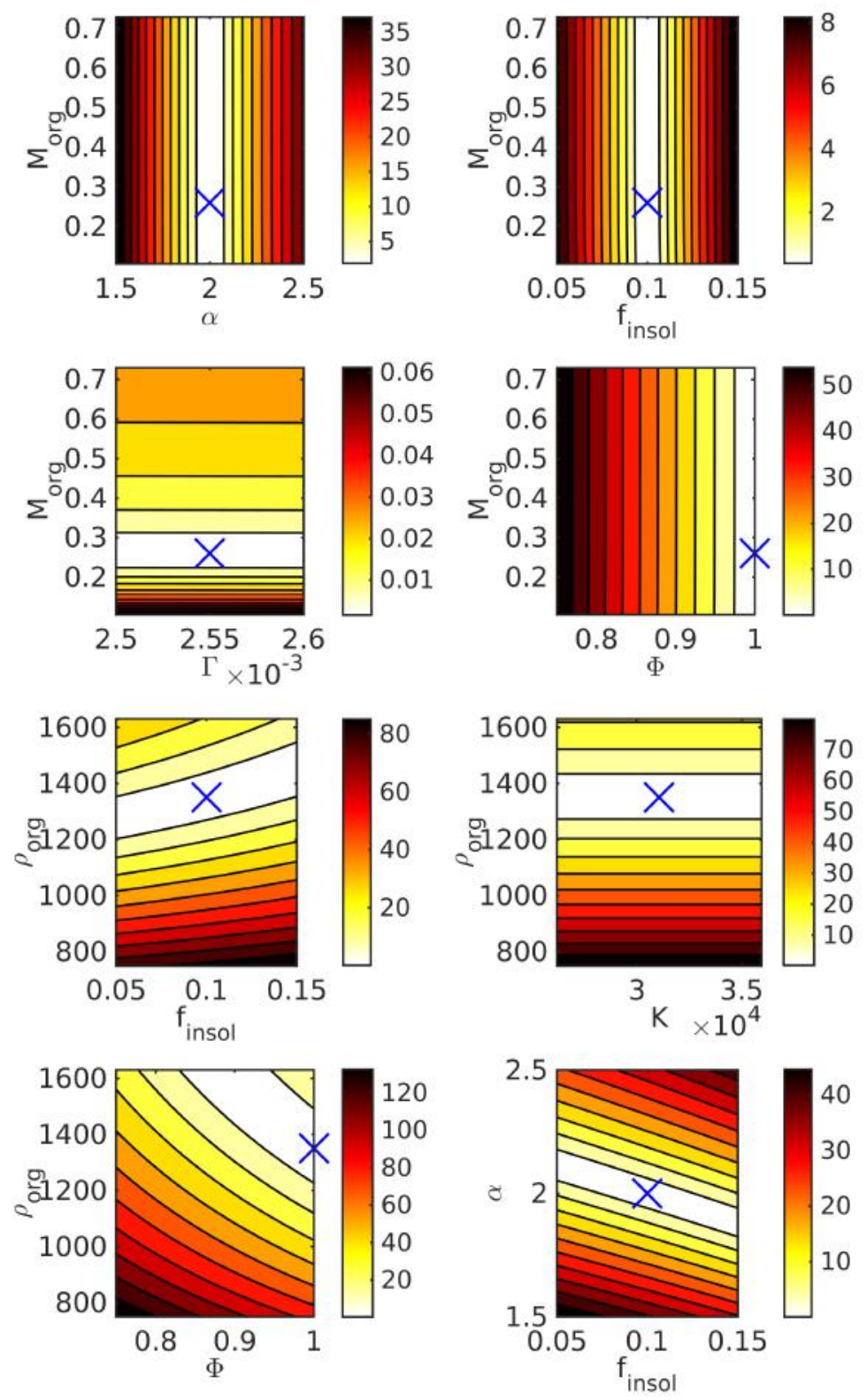

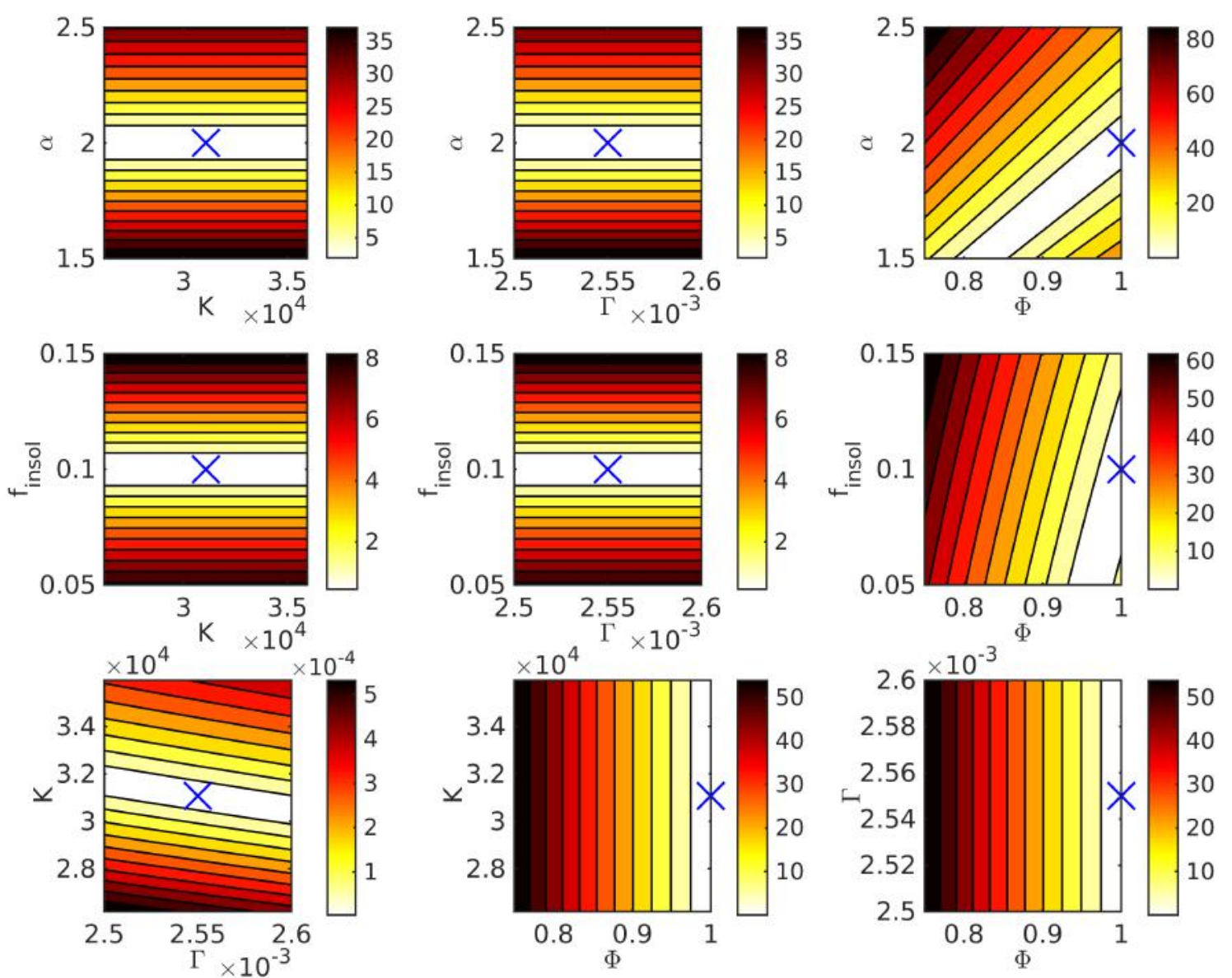


\subsection{Polluted continental}

\subsubsection{Case 1: $a_{w}^{n p} \sigma^{f}$}
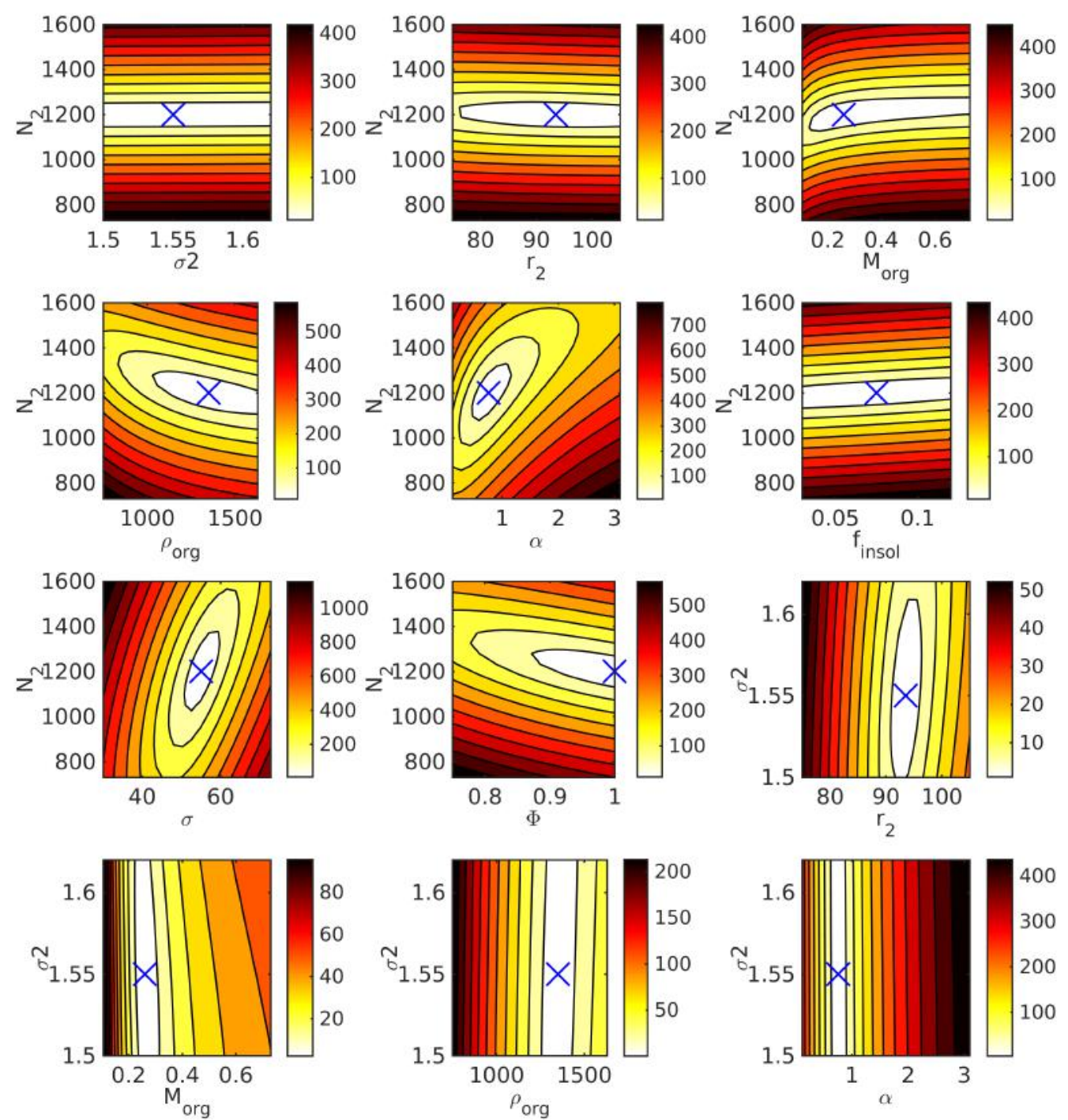

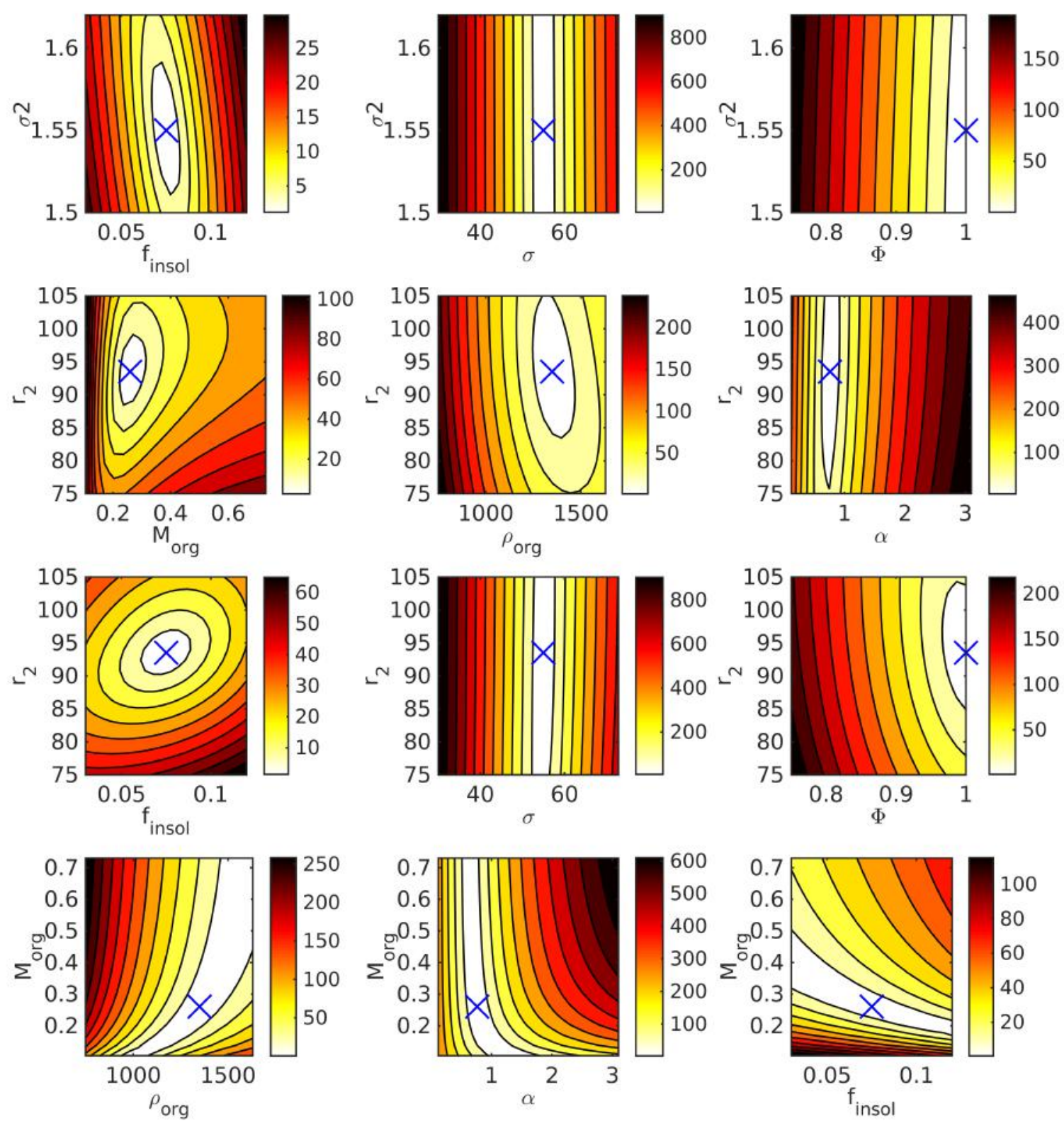

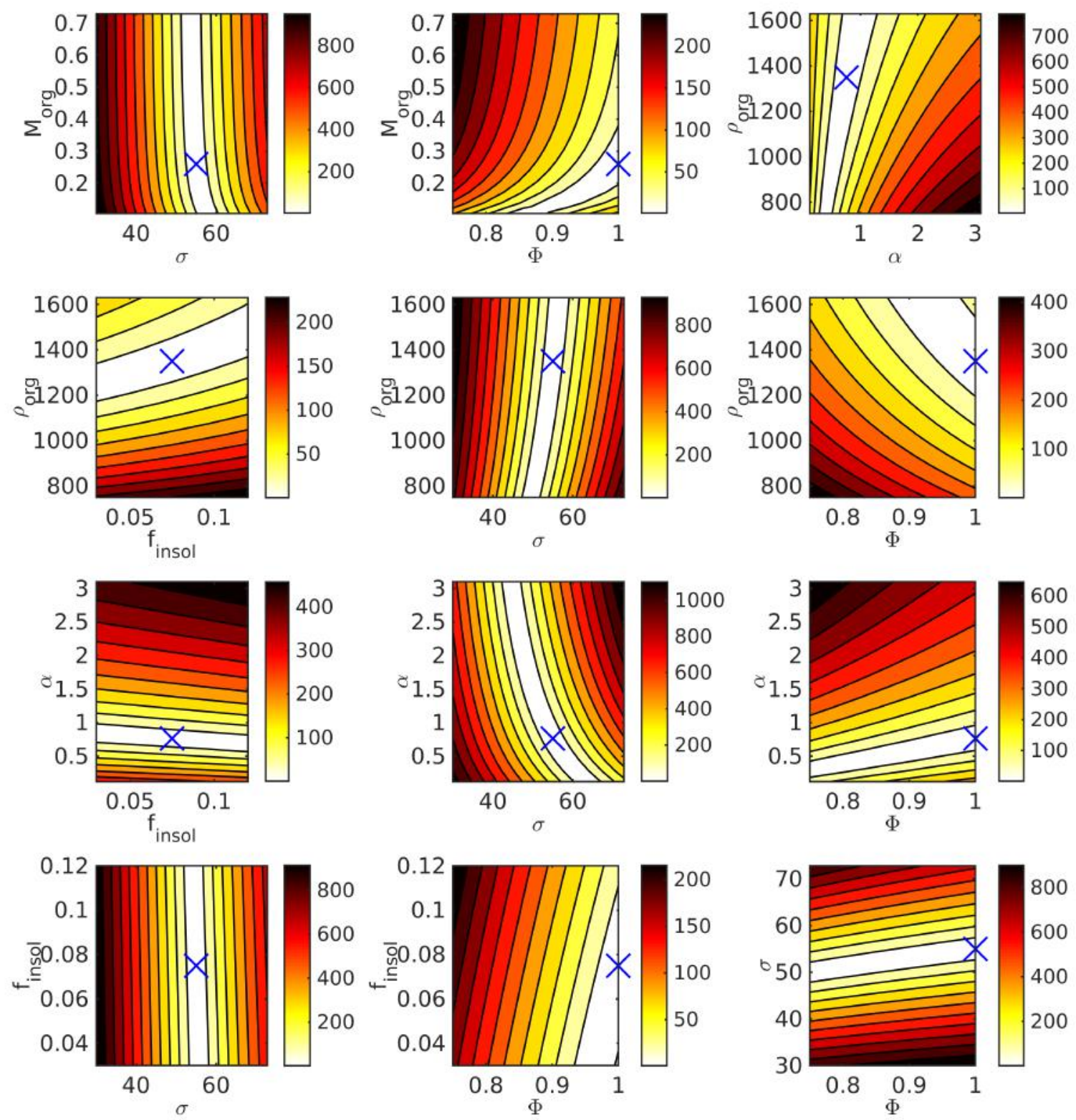
1.3.2 Case 2: $a_{w}^{p} \sigma^{f}$
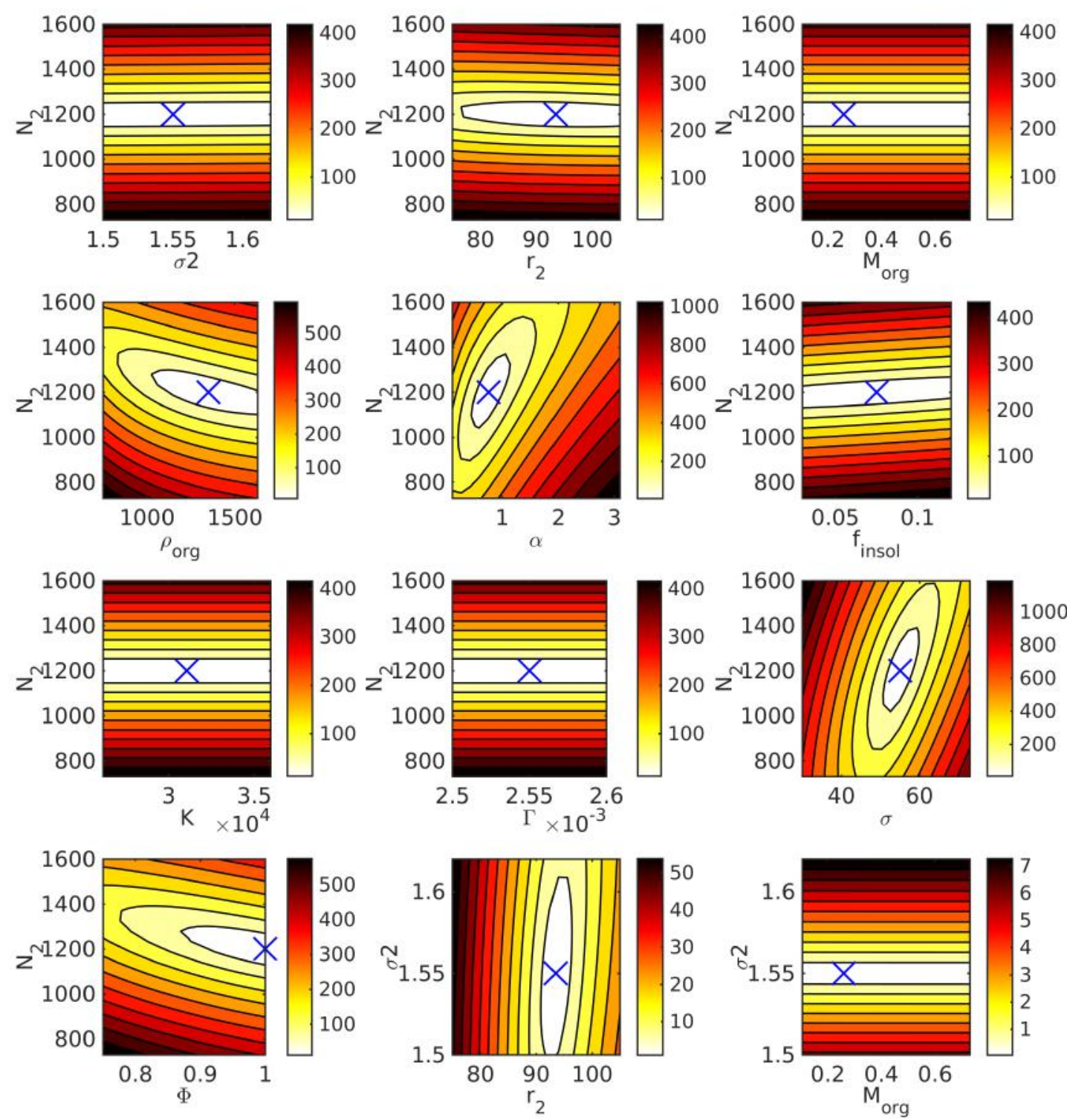

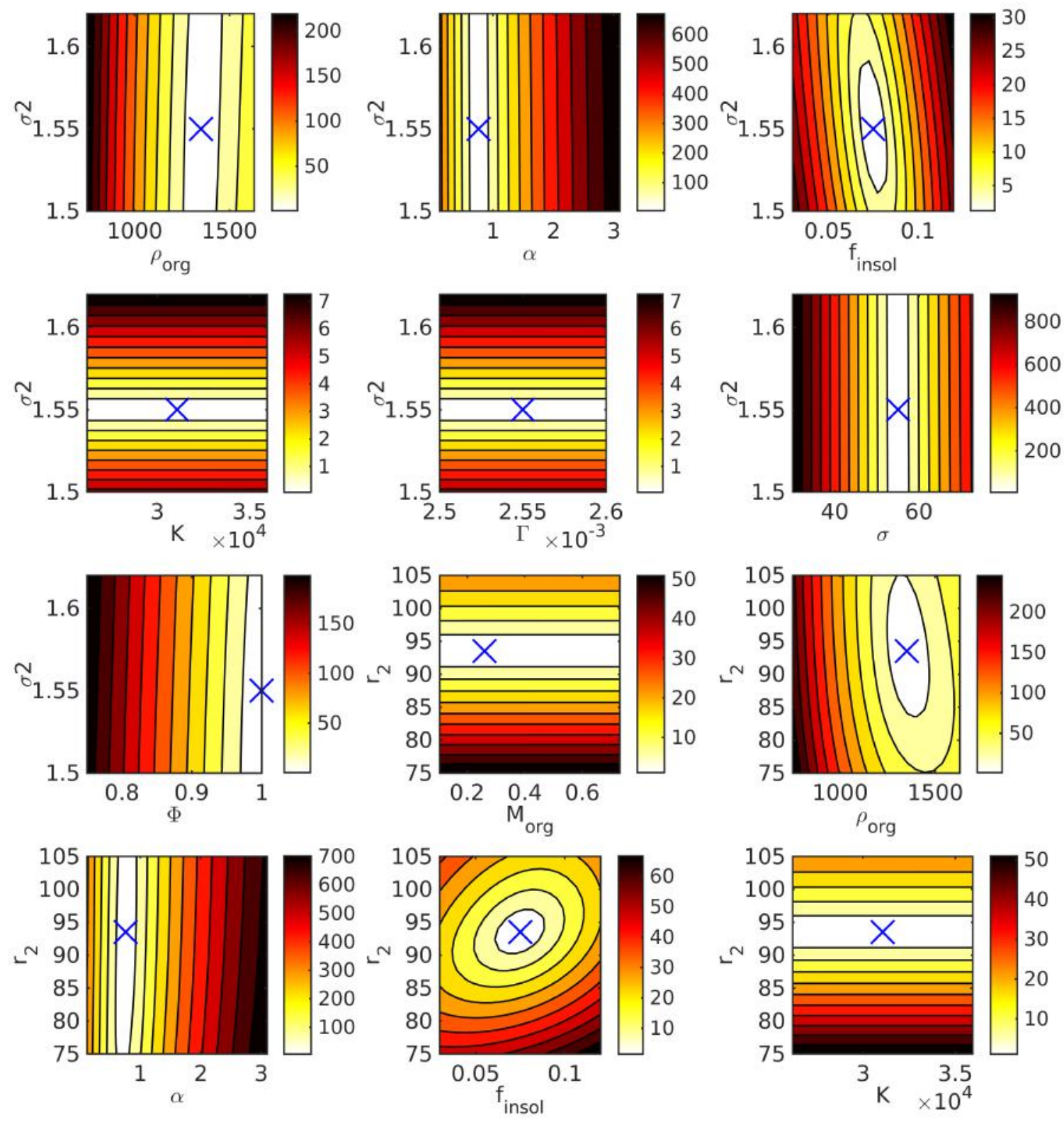

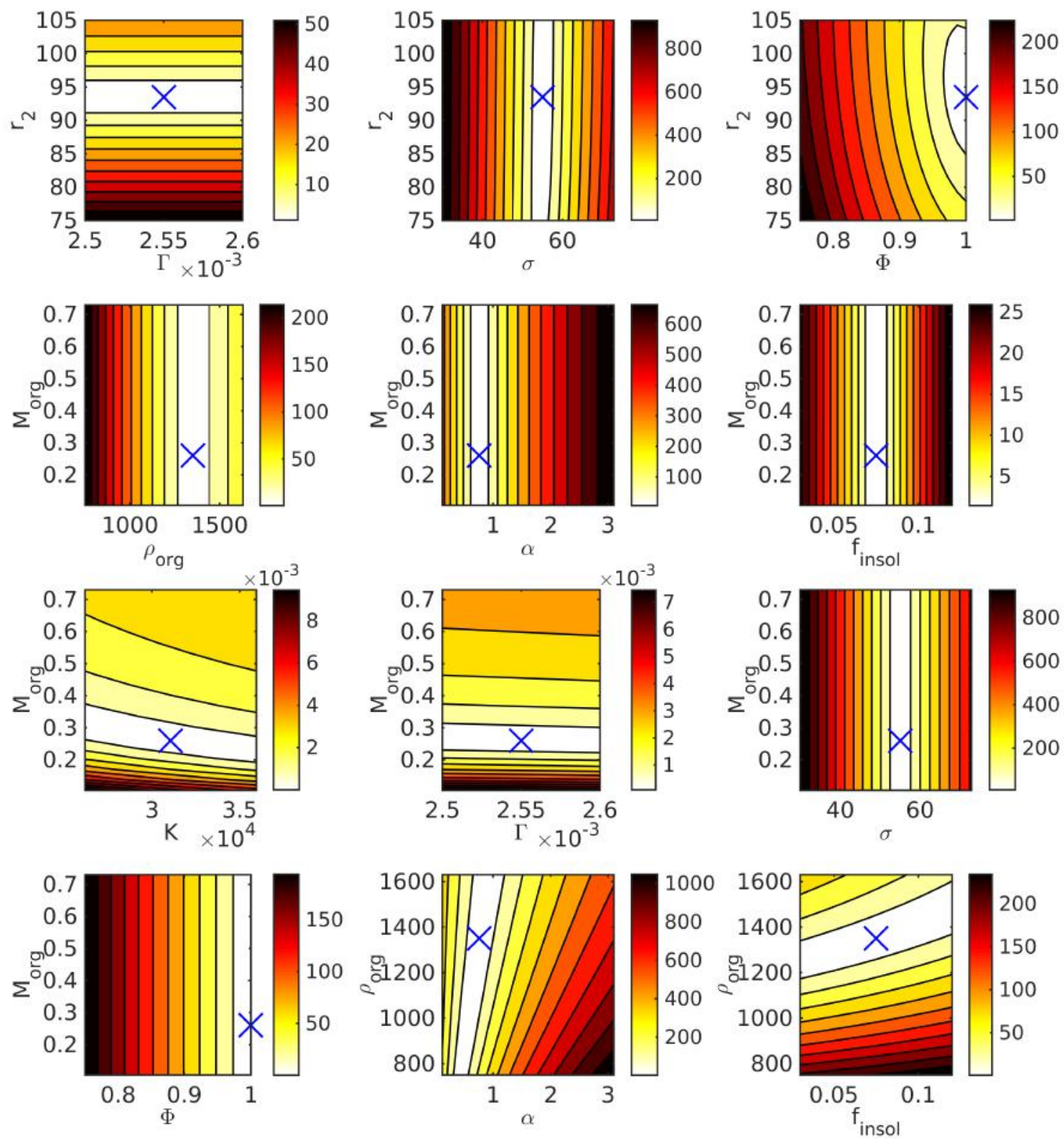

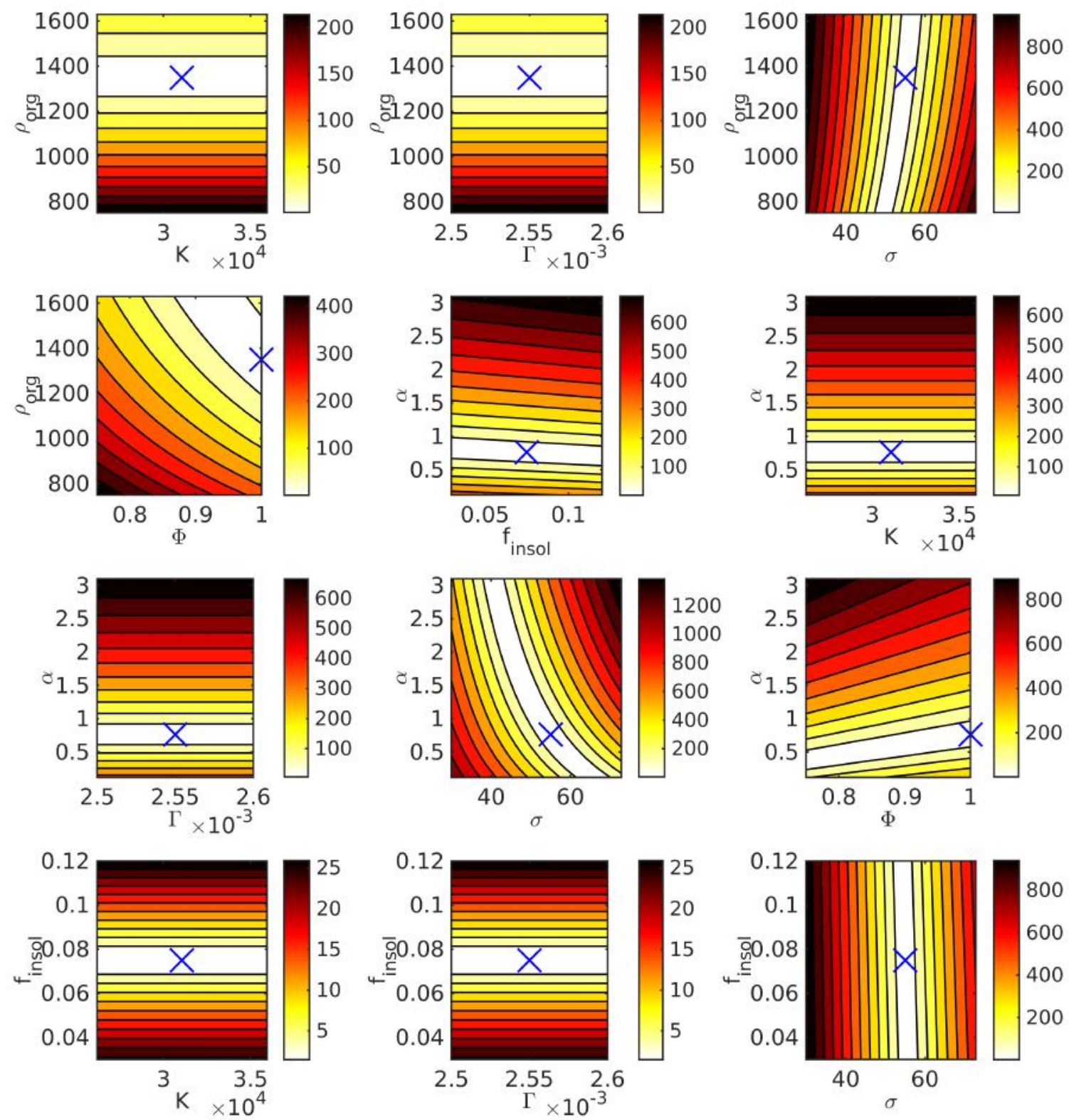

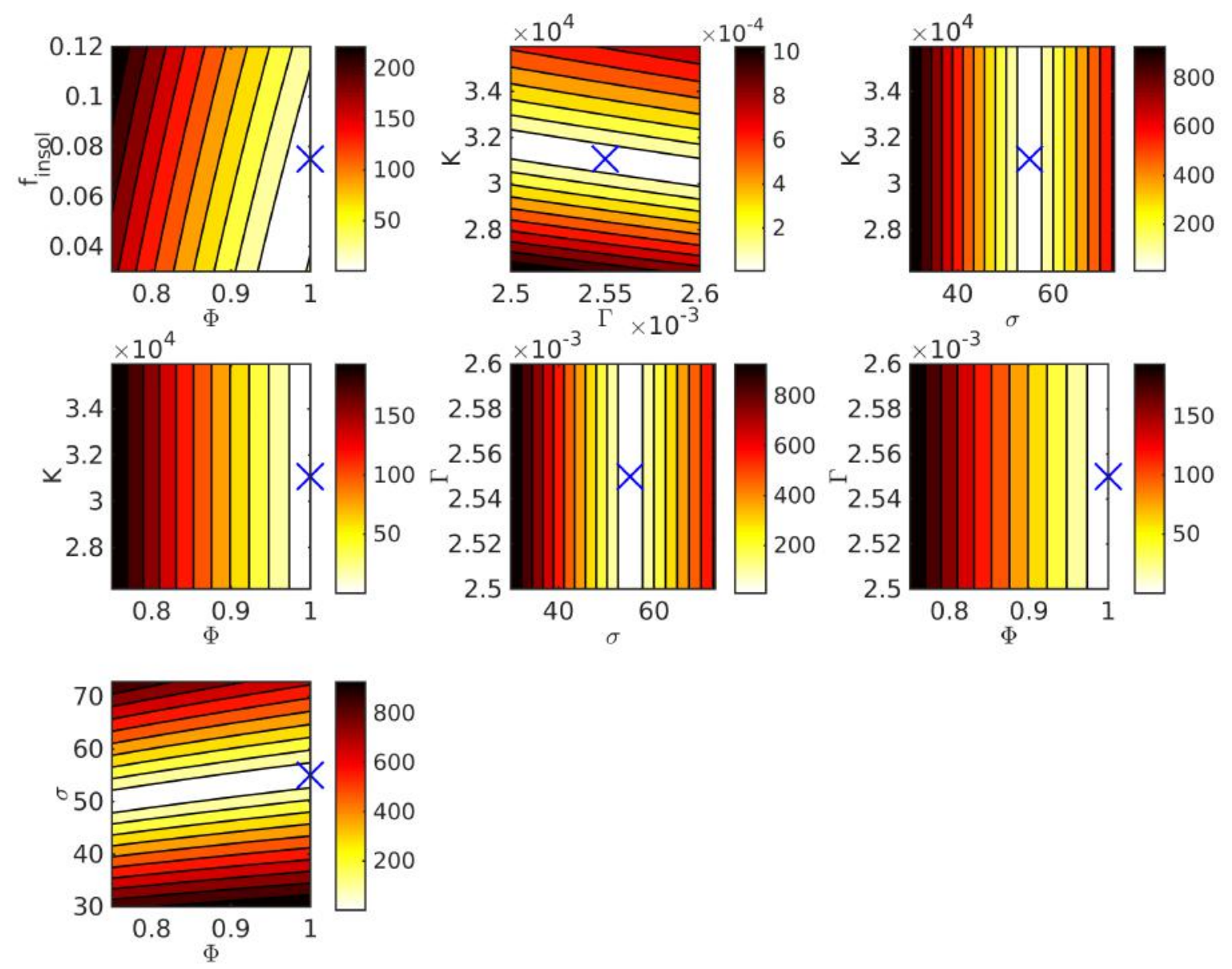
1.3.3 Case 3: $a_{w}^{n p} \sigma^{n f}$
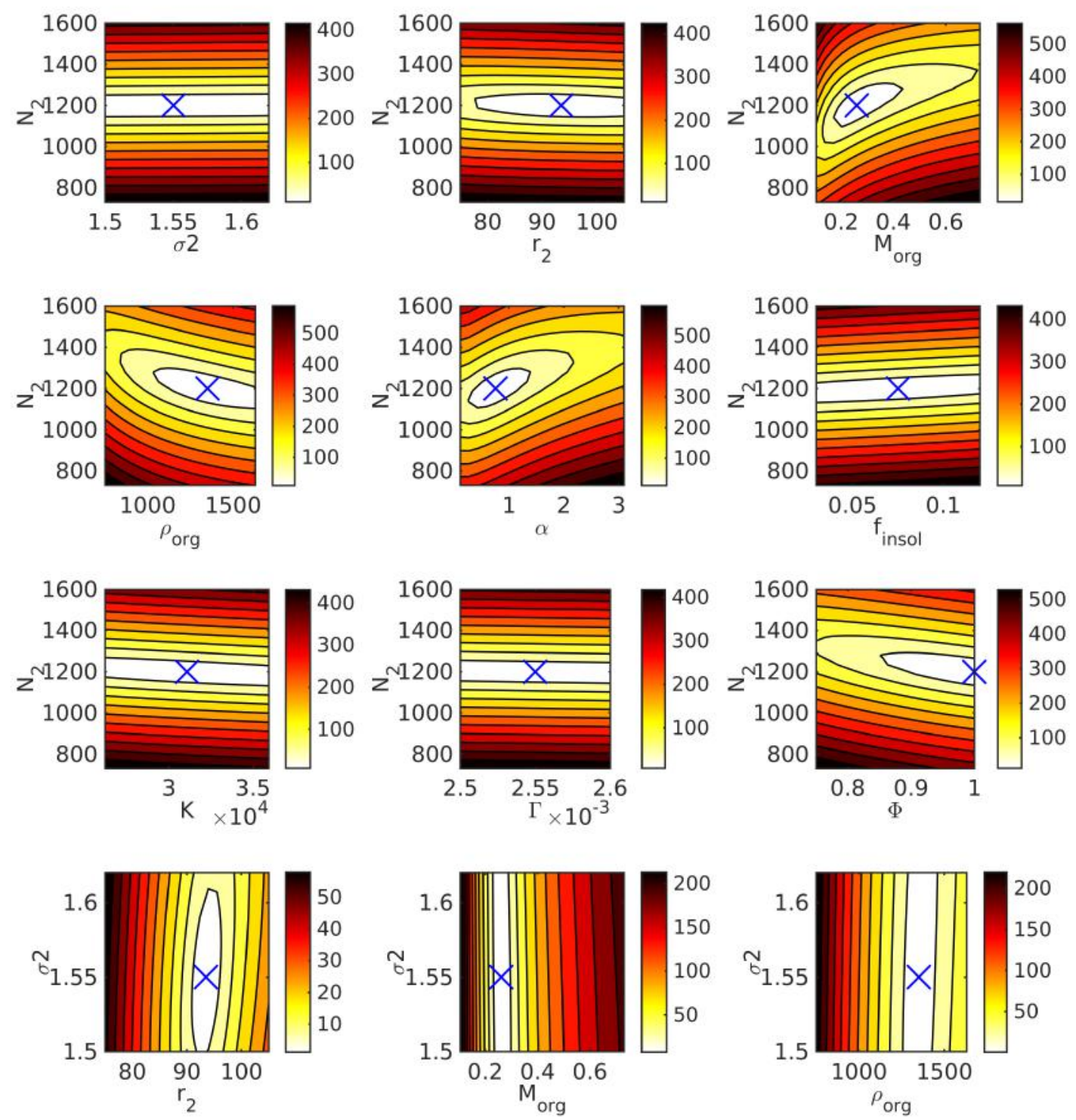

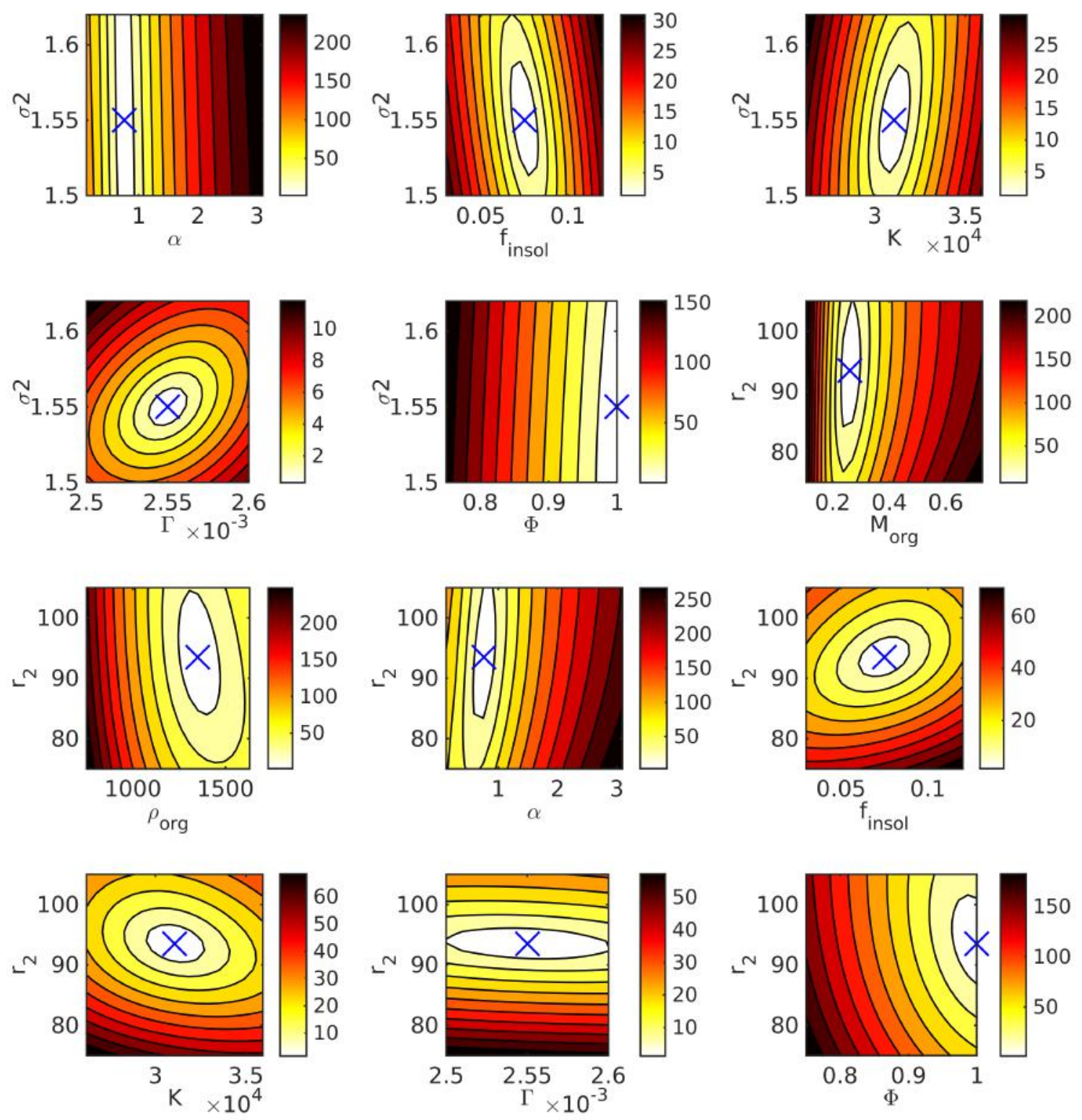

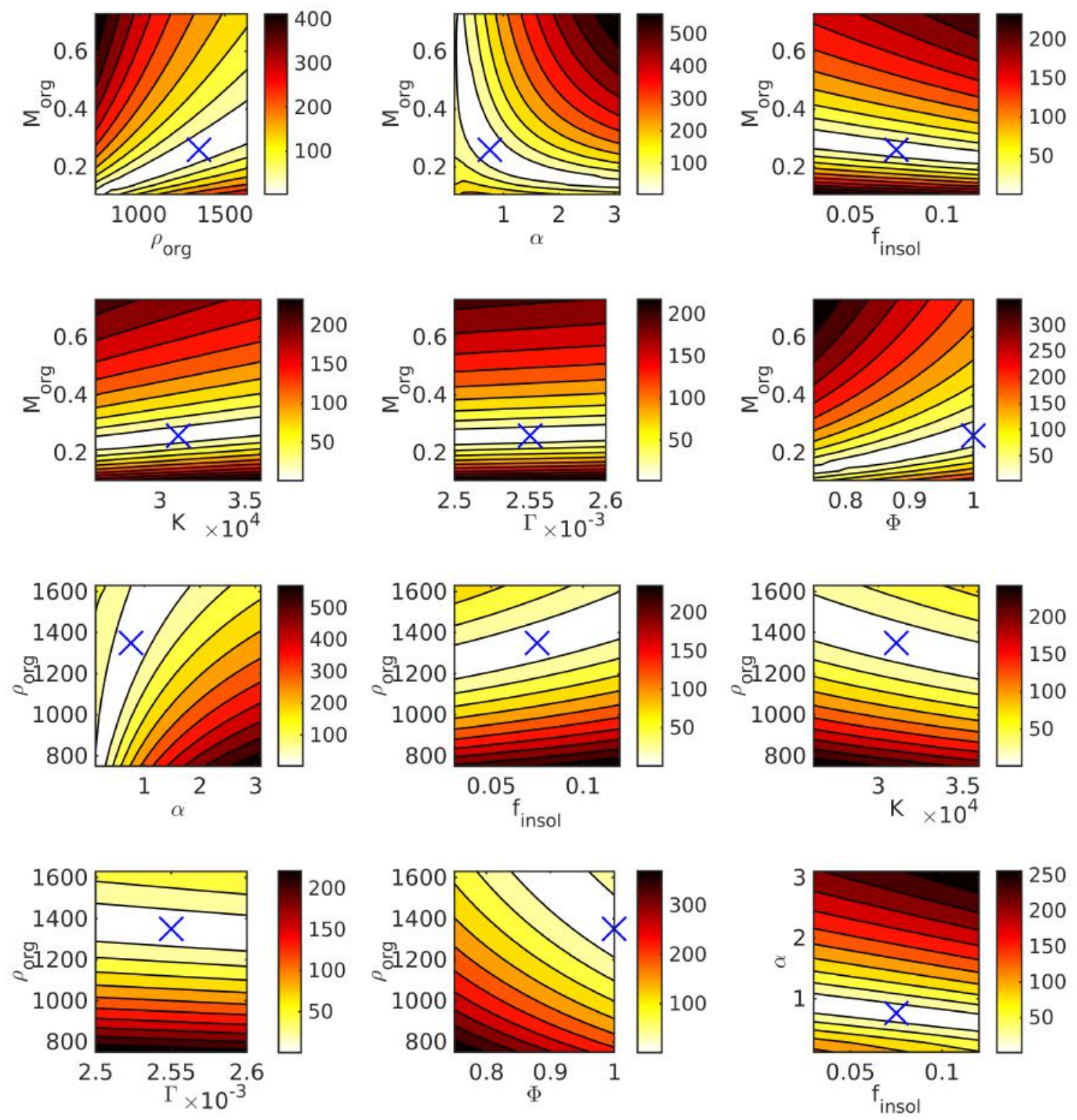

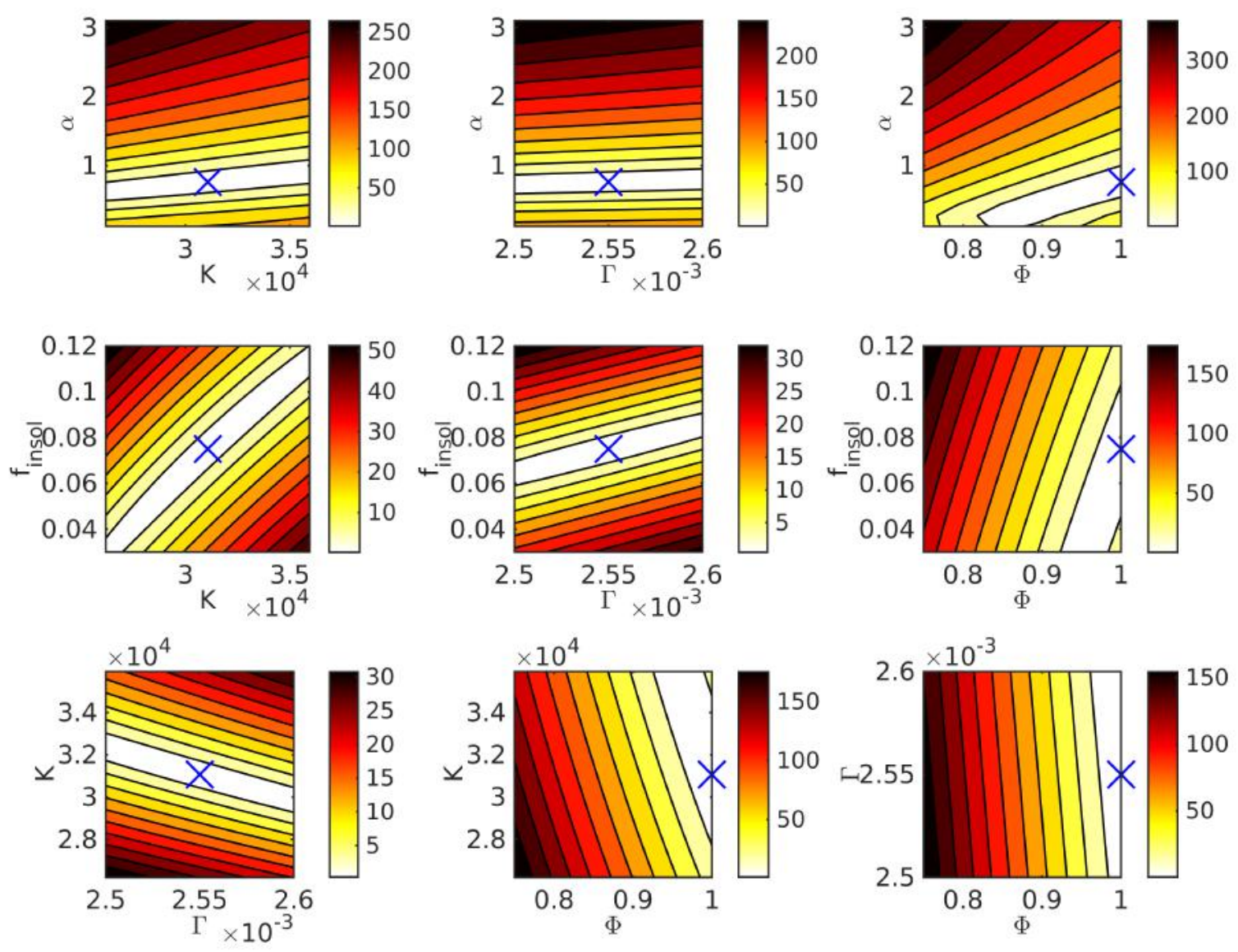

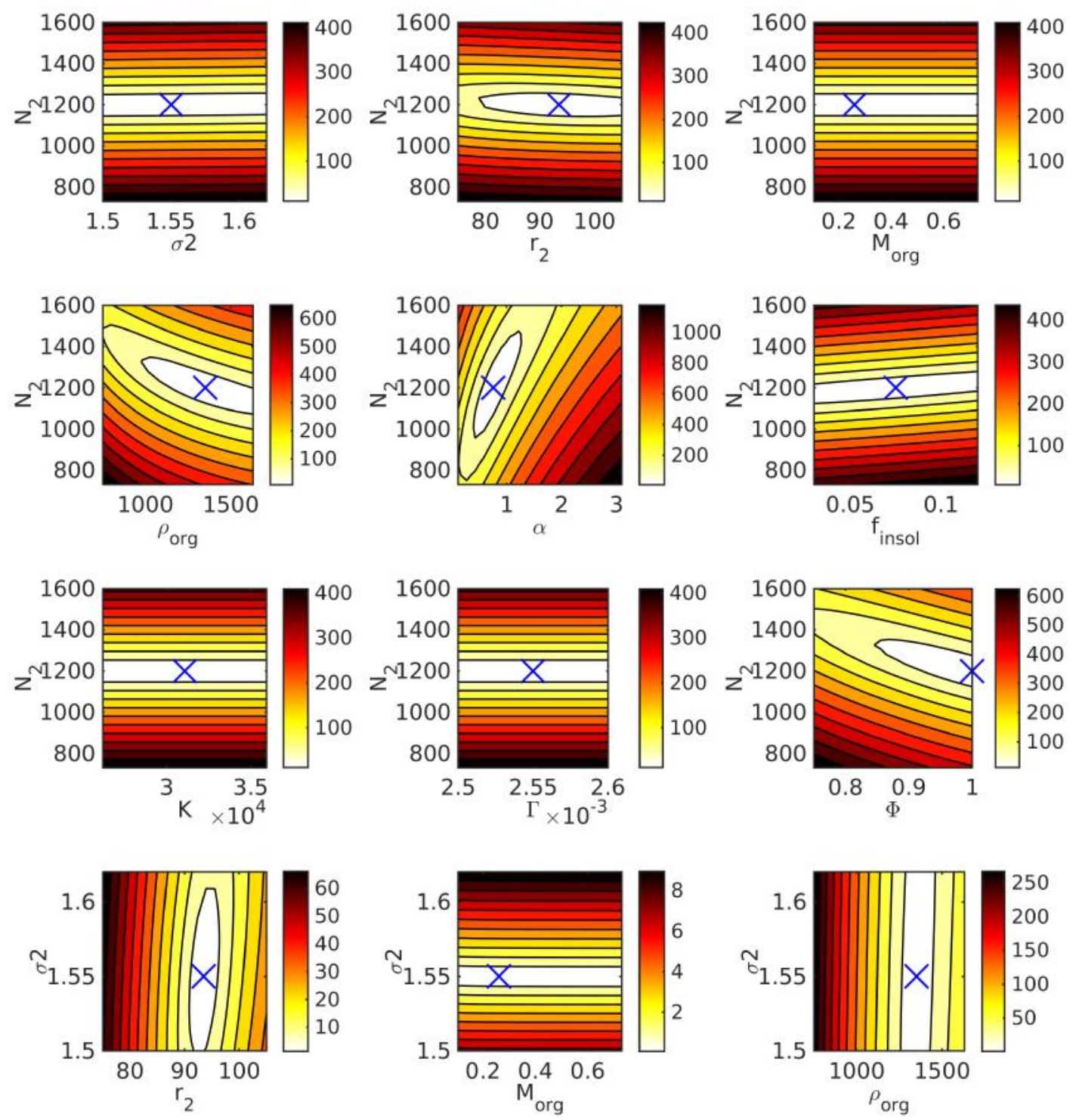

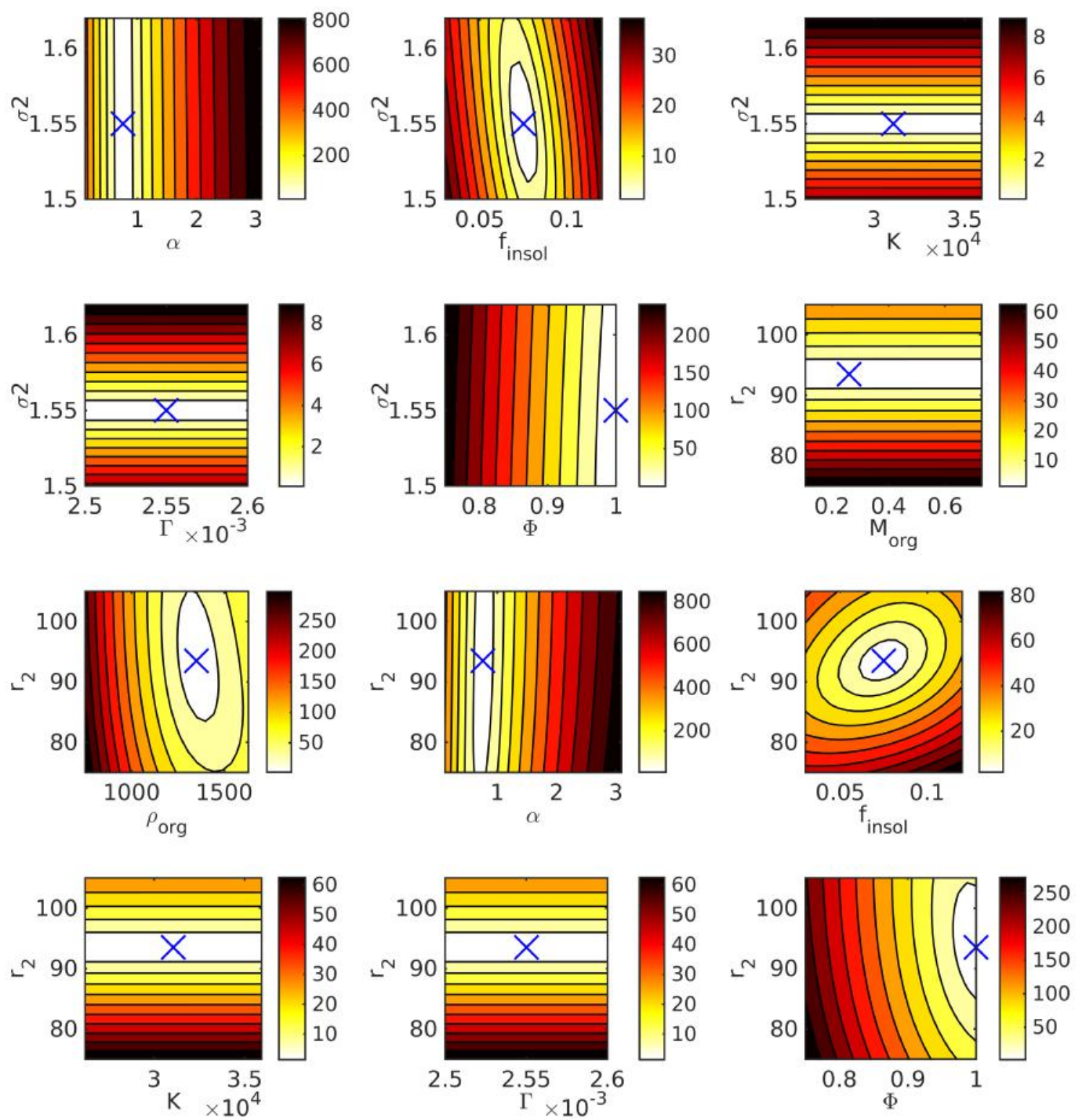

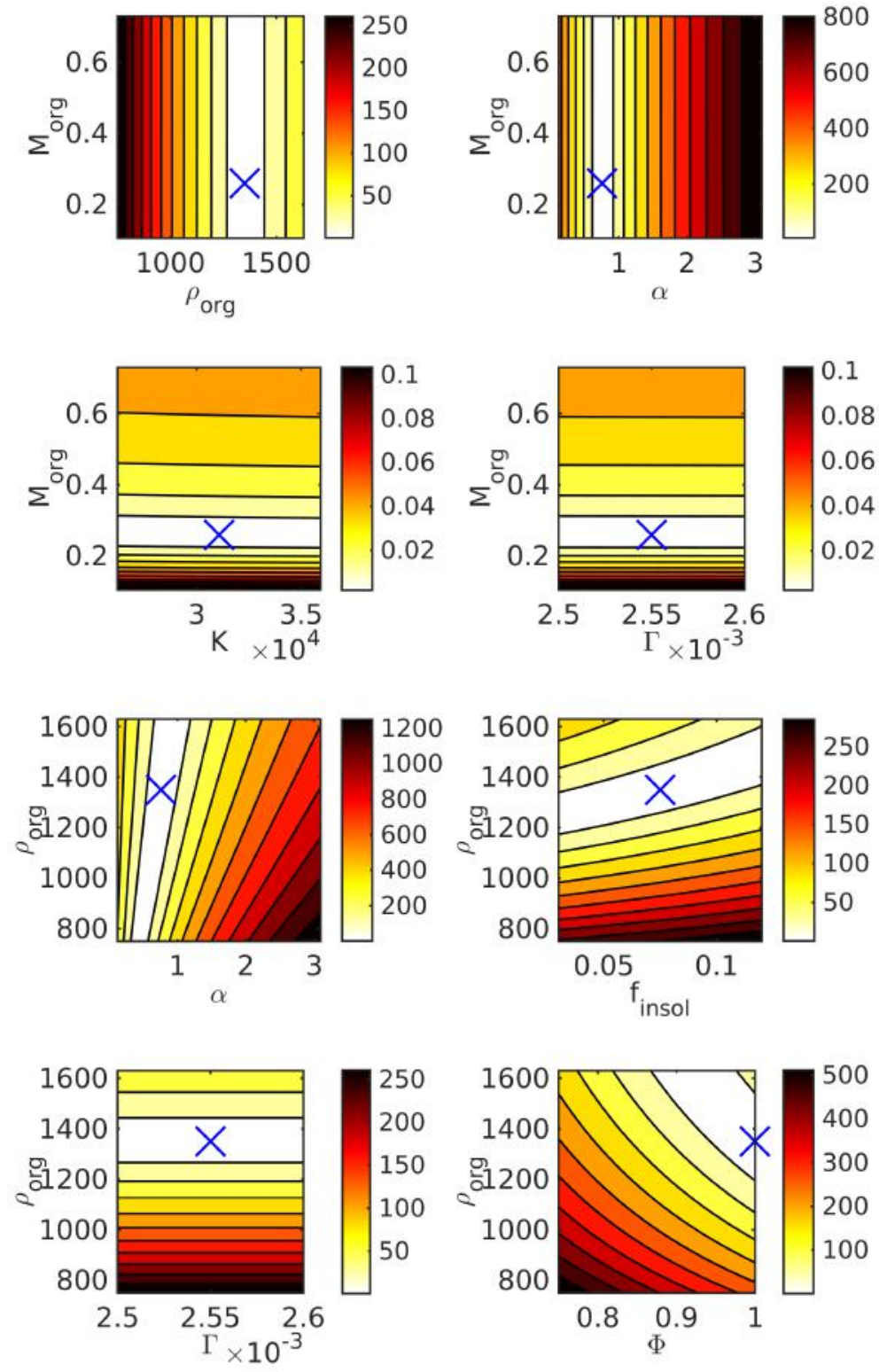
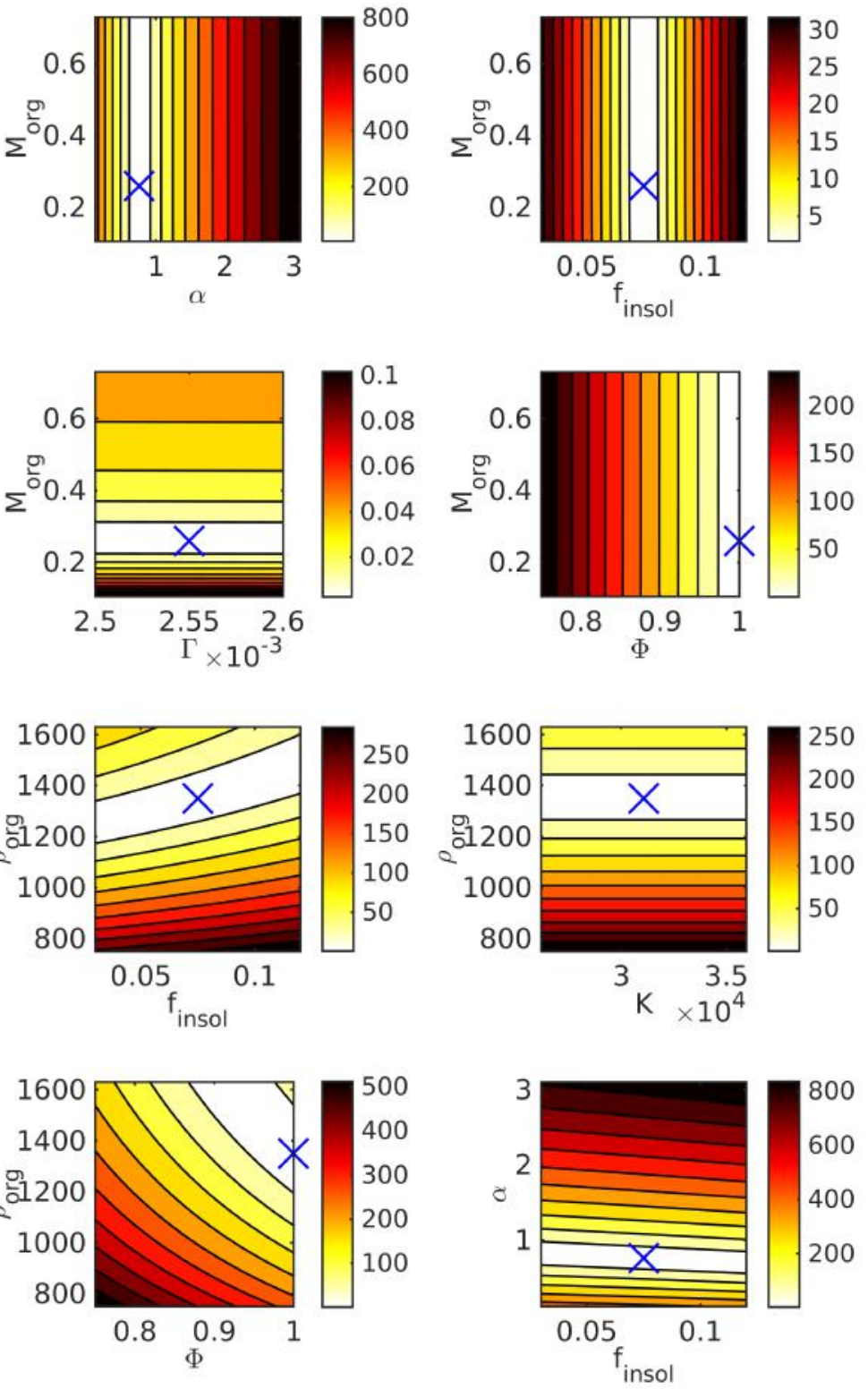

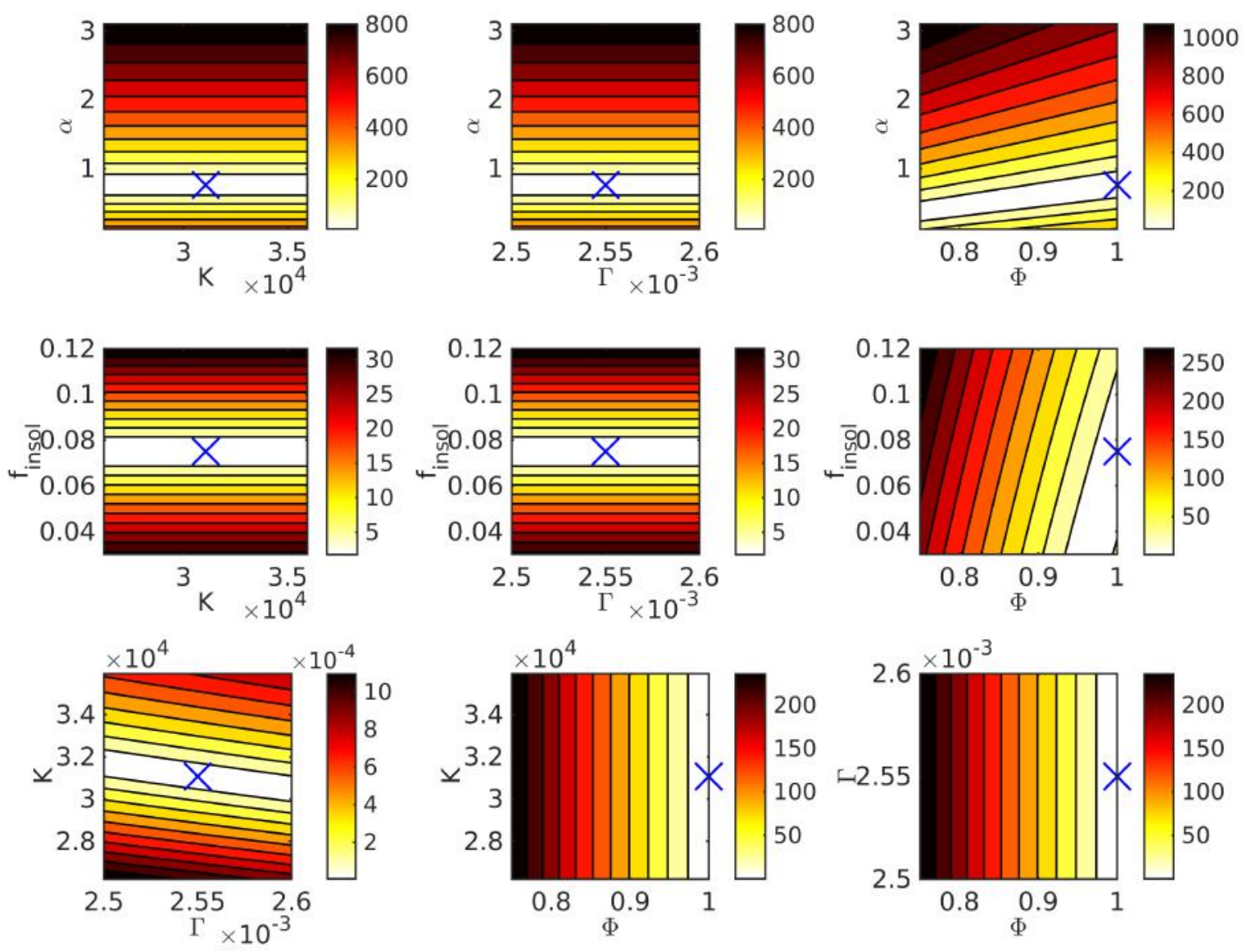